\title{
WHY MATTER MATTERS: HOW TECHNOLOGY CHARACTERISTICS SHAPE THE STRATEGIC FRAMING OF TECHNOLOGIES
}

\author{
Joern Hoppmann $^{12} *$, Laura Diaz Anadon ${ }^{34}$, Venkatesh Narayanamurti $^{35}$
}

${ }^{1}$ University of Oldenburg, Department of Department of Business Administration, Economics, and Law, Ammerlaender Heerstr. 114-118, 26129 Oldenburg, Germany

${ }^{2}$ ETH Zurich, Department of Management, Technology, and Economics Weinbergstrasse 56/58, 8092 Zurich, Switzerland

${ }^{3}$ Harvard University, Belfer Center for Science \& International Affairs

79 John F. Kennedy Street, Cambridge, MA 02138

${ }^{4}$ University of Cambridge, Department of Land Economy, Silver Street, Cambridge, CB3 9EP, United Kingdom

${ }^{5}$ Harvard University, John A. Paulson School of Engineering and Applied Sciences 29 Oxford Street, Cambridge, MA 02138

*Email: joern.hoppmann@uol.de, Phone: +49-441 7984182

\section{Forthcoming in Research Policy}

Please cite this article as: Hoppmann, J., Anadon, L.D., Narayanamurti, V. (2019). Why matter matters: how technology characteristics shape the strategic framing of technologies. Research Policy, in press. 


\begin{abstract}
Previous work stresses that actors use strategic technology framing-i.e. purposeful language and rhetoric - to shape technology expectations, persuade stakeholders, and influence the evolution of technologies along their life-cycle. Currently, however, the literature predominantly describes strategic technology framing as a sociopolitical process, and provides only limited insights into how the framing itself is shaped by the material characteristics of the technologies being framed. To address this shortcoming, we conducted a comparative, longitudinal case study of two leading research organizations in the United States and Germany pursuing competing solar photovoltaic (PV) technologies to examine how technology characteristics shape the strategic framing of technologies. We show that to frame PV technologies in their own favor, executives made use of four framing dimensions (potential, prospect, performance, and progress) and three framing tactics (conclusion, conditioning, and concession). Moreover, we show that which framing dimensions and tactics actors selected depended on the maturity and evolution of the technology they pursued, respectively. By highlighting how technology characteristics shape strategic technology framing, we contribute to the literatures on social movements, institutional entrepreneurship, and impression management. Additionally, by providing a coherent framework of strategic technology framing, our study complements existing findings in the literature on the sociology of expectations and contributes to a better understanding of how technology hypes emerge.
\end{abstract}

Keywords: Technology characteristics, framing, sociology of expectations, technology hypes, solar photovoltaic 


\section{INTRODUCTION}

Technological change is a process rife with uncertainty. Especially early in the technology life-cycle, many technological alternatives compete for attention, even though neither their performance nor the criteria to evaluate it are yet clear (Anderson and Tushman, 1990; Kaplan and Tripsas, 2008). This uncertainty allows actors to strategically influence others' beliefs and expectations of technologies in their own interest. For example, existing studies show that actors working on novel technologies systematically try to influence the technology expectations of important stakeholders to generate legitimacy and mobilize resources for their own technology (Borup et al., 2006). Since stakeholders' expectations and beliefs determine organizations' access to financial, technological, and human resources, such efforts can significantly enhance organizational performance and prospects (Garud et al., 2002) and may also shape the evolution of technologies along the life-cycle (Kaplan and Tripsas, 2008).

While actors have been shown to use various means to persuade stakeholders, such as technology demonstrations or pilot projects, studies highlight the important role of public framing through language (Cornelissen and Werner, 2014). The term "framing" has been used to describe both (a) cognitive processes of information filtering and interpretation that help individuals make sense of cues in complex environments, and (b) social processes where actors purposefully use language to influence others' interpretation of objects and events, and ultimately change their behavior (Cornelissen and Werner, 2014). In this study, we draw on the latter definition, which conceives framing as an active, public act where individuals construct narratives in order to persuade stakeholders (Goffman, 1974). Indeed, scholars in the fields of organization theory, impression management, and persuasion studies stress that actors use framing in strategic - i.e., purposefulways, and have studied the rhetoric and tactics that executives use to give meaning to events, improve corporate image, and mobilize support for change (Bolino et al., 2008; Kaplan, 2008). 
Despite evidence that framing can decisively shape perceptions and expectations of technologies, however, we currently lack detailed insights into what framing strategies actors use, and how. Work drawing on institutional entrepreneurship and social movement theory has concentrated on sociopolitical variables when studying framing's antecedents and nature. For example, it has been shown that framing is strongly driven by the actor's own interests, and is most effective if it presents issues in a way that resonates with the audience (Garud and Rappa, 1994; Kaplan, 2008). However, these studies have not investigated in detail how strategic framing depends on the characteristics of the framed technology-i.e., its empirically observable, material properties and evolution over time.

Studies in the field of the social construction of technology (Pinch and Bijker, 1984), technology-in-practice (Orlikowski, 2008), and sociomateriality (Orlikowski, 2007) stress that materiality matters, but without exploring how technology characteristics shape framing strategies aimed at influencing the expectations and beliefs of important stakeholders. One stream that more explicitly accounts for materiality when analyzing the narratives actors use to shape others' perception of technologies is that on the sociology of expectations. This literature shows that to frame technology expectations credibly, actors tie together accounts of the past, present, and future (Brown and Michael, 2003); speak of the technology's performance, historical progress, path forward, and end targets (Bakker et al., 2012); and combine positive statements with more modest or negative ones (Gardner et al., 2015). Despite these valuable insights, however, the literature on sociology of expectations focuses on how strategic technology framing shapes material factors, rather than vice versa and does not provide a coherent framework showing how specific technology characteristics affect actors' framing strategies (Borup et al., 2006).

A deeper understanding of how material factors influence strategic technology framing is essential, as it provides important insights into the agency actors have in framing technologies. 
Moreover, studying strategic technology framing is important to understand the emergence of technology hypes as situations where actors' claims (both technology developers' and other stakeholders') deviate from material developments, get picked up by others, and are translated into investments in potentially inferior technological options. For example, recent work on the sociology of expectations stresses that exaggerations by framing actors may spur future disappointments among important stakeholders (Borup et al., 2006; Garud et al., 2014). The fact that such disappointments may lead stakeholders to withdraw their support and damage the actor's credibility raises the question of how technology characteristics shape the strategic framing of technologies.

In this paper, we use a comparative, longitudinal case study to analyze the framing used by executives at the world's two largest research institutes working on solar photovoltaic (PV) power: the National Renewable Energy Laboratory (NREL) in Golden, USA and the Fraunhofer Institute for Solar Energy Systems (Fraunhofer ISE) in Freiburg, Germany. These organizations are well suited for our analysis since they focused on competing PV technologies that possessed different characteristics, while facing considerable uncertainty about which one would come out on top. Executives in the two organizations responded to this uncertainty by using framing that varied both across organizations and over time, allowing us to study in detail how technology characteristics, such as technology maturity and evolution, shape patterns of strategic technology framing.

Our research makes several contributions. First, it advances the literature on social movements, institutional entrepreneurship, and impression management by highlighting the important role of materiality in strategic technology framing. Empirical studies in these fields portray strategic technology framing as primarily driven by sociopolitical factors (Cornelissen and Werner, 2014). Our study indicates that material technology characteristics influence strategic framing in important ways, thereby complementing existing frameworks and answering recent calls to study the antecedents of framing (Borah, 2011; Cornelissen and Werner, 2014). 
Second, our study builds on and extends the literature on the sociology of expectations. While this literature provides valuable insights into how individuals construct narratives to shape stakeholders' expectations, it lacks coherent frameworks linking technology characteristics to actors' strategic framing of technologies. We show that executives used four framing dimensions and three framing tactics, which they systematically tailored to the maturity and evolution of their own technologies. Reflecting these material factors in their framing allows actors to paint a more credible account of the strengths of their favored technology and reduces the risk of future disappointments.

Third, our study also contributes to the literature on technology hypes by detailing the mechanisms through which strategic technology framing contributes to inflated expectations. We show how tailoring framing to particular technology characteristics allows actors to convey positive expectations about technologies, while distracting from material developments that favor alternatives. In this sense, our framework may help technology developers and other stakeholders identify exaggerated promises and technology hypes.

\section{THEORETICAL BACKGROUND}

\section{The role of expectations and beliefs in technology evolution and competition}

The dynamics of technology competition and their implications for organizations have long been of interest to scholars in the field of management and technological change (Dosi, 1982; Tushman and Anderson, 1986). Particularly at early stages of the technology life-cycle when new technologies emerge, organizations usually face considerable uncertainty (Anderson and Tushman, 1990). This is because new technologies often cannot be objectively assessed using well-established evaluation routines (Constant, 1980; Van den Belt and Rip, 1987). Moreover, actors need to assess technologies' future, as well as present, performance. Such an assessment, however, is complicated by the fact that the most appropriate evaluation criteria, applications, and markets are rarely known in advance, and 
also evolve over time (Anderson and Tushman, 1990; Garud and Rappa, 1994; Santos and Eisenhardt, 2009). Therefore, the assessment of technologies depends heavily on expectations and beliefs (Benner and Tripsas, 2012; Kaplan and Tripsas, 2008), particularly at early stages of the technology life-cycle.

The importance of expectations and beliefs in times of technological uncertainty creates both the possibility and an incentive for actors to engage in strategic behavior aimed at influencing the beliefs and expectations of others (Alkemade and Suurs, 2012; Kaplan and Tripsas, 2008). For example, by generating favorable beliefs and expectations, actors pursuing a specific technology can enhance its legitimacy among critical stakeholders, such as customers, investors, and employees

(Aldrich and Fiol, 1994; Brown and Michael, 2003); ensure the supply of financial and human resources (Garud et al., 2002); and stimulate investments into complementary technological solutions (Konrad et al., 2012). Overall, by influencing expectations and beliefs, organizations can shape their institutional environment, chances of organizational survival, and the evolution of technologies (Garud et al., 2002; Kaplan and Tripsas, 2008).

\section{Strategic framing as a way to shape expectations and beliefs}

But how can actors influence others' expectations and beliefs about technologies? Previous studies demonstrate that one crucial method is framing (Cornelissen and Werner, 2014). In the literature, the term "framing" has been used to describe both (a) cognitive processes of information filtering and interpretation that help individuals make sense of cues in complex environments, and (b) social processes where actors purposefully use language to influence others' interpretation of objects and events and ultimately change their behavior (Cornelissen and Werner, 2014). In this study, we draw on the latter definition, which conceives framing as an active, public act in which individuals construct narratives in a purposeful attempt to persuade stakeholders (Goffman, 1974). Indeed, 
studies in the field of organization theory, impression management, and persuasion studies demonstrate that actors, e.g., executives, use framing strategically to give meaning to organizational events, improve corporate image, and mobilize support for change (Bolino et al., 2008; Gioia and Chittipeddi, 1991; Kaplan, 2008; Maitlis and Lawrence, 2007). For example, studies in the fields of organization theory and persuasion studies show that strategic framing involves the use of analogies, metaphors, narratives, and the portrayal of events as opportunities or threats (Cornelissen et al., 2011; Gilbert, 2006; Sonenshein, 2010) and that whether a message is persuasive depends on the delivery style, length, repetition, speed of speech, and vividness (Bator and Cialdini, 2000).

More detailed insights into how individuals deploy and combine such rhetorical elements to achieve desired ends are contained in the literature on impression management, which describes how individuals and organizations purposefully use language to enhance their image, or to maintain or regain legitimacy after controversial events (Elsbach, 1994; Leary and Kowalski, 1990). Studies show that actors use a variety of tactics to achieve these aims, such as concealing negative events (Sutton and Callahan, 1987); redefining events by selectively highlighting certain properties (Elsbach, 1994); denying responsibility for negative events (Staw et al., 1983); or offering excuses, disclaimers, or justifications that seek to explain the framer's own behavior and portray them in a positive light (Marcus and Goodman, 1991; Schlenker, 1980; Tilly, 2006). For example, studying verbal accounts used by spokespersons in the California cattle industry, Elsbach (1994) found that acknowledgement was more effective than denial when companies sought to restore organizational legitimacy in the face of controversial events. In a different study, Elsbach et al. (1998) showed how hospitals used anticipatory impression management tactics, such as excuses, justifications, and obfuscations, to reduce patient complaints during the introduction of controversial billing practices.

\section{Drivers and constraints of strategic framing efforts}


Organizational scholars have also started to clarify the factors driving and constraining actors' framing efforts. In this context, recent studies on strategic technology framing typically draw on frameworks and theories developed in the fields of institutional entrepreneurship (Garud et al., 2002; Kaplan and Murray, 2010; Lounsbury and Glynn, 2001) and social movements (Benford and Snow, 2000; Snow et al., 1986), which have long been interested in how actors can use purposeful framing to change formal and informal institutions. Not surprisingly, framing in this literature has been portrayed as being strongly driven and shaped by sociopolitical variables, such as individual interests, discursive opportunities, the framing audience, as well as the framing channel.

First, scholars have pointed out that framing is strongly driven by individual interests (Kaplan and Tripsas, 2008). For example, building on social movement theory, Kaplan (2008) describes how actors in the communication technology industry used skillful framing to push other organizational members toward supporting their preferred choice of technology. Similarly, Garud and Rappa (1994) show how organizations working on cochlear implants made use of systematic framing to convince regulatory bodies of the superiority of their own technological choice. In both studies, framing is portrayed as mediating between actors' political interest and others' beliefs and expectations (Cornelissen and Werner, 2014).

Second, studies show that framing is particularly effective if it exploits discursive opportunities (Martens et al., 2007; McCammon et al., 2007; Snow et al., 1986), i.e., "salient discourses that are alive and have momentum at a particular point in time" (Werner and Cornelissen, 2014, p. 1461). Framing that is embedded in the right broader discourse may appear much more sensible, realistic, and legitimate (Fiss and Hirsch, 2005; Kellogg, 2011; Koopmans and Statham, 1999; Martens et al., 2007). For example, Van Lente (2000) shows how producers of high-definition TV used framing linked to the broader notion of "technological progress" to create what he calls a "forceful future." 
Third, effective framing has been shown to use narratives that resonate with the target audience, i.e., that are "congruent with the audiences' observations, experience, and cultural knowledge" (Benford, 1993, p. 699). Kaplan (2008), for example, demonstrates that in order to influence decisions about technology investments in their favor, actors used framing to make their frames resonate with other organizational members. Thus, even when trying to alter the rules of the game, skilled actors rely on legitimacy and make use of familiar language and cultural symbols (Creed et al., 2002; Gray et al., 2015; Green et al., 2009; Kennedy and Fiss, 2009; McInerney, 2008; Snow and Benford, 1988). In line with this, recent research demonstrates that actors' framing closely follows the demands of the most important stakeholders (Fiss and Zajac, 2006; Giorgi and Weber, 2015; Gurses and Ozcan, 2015) and that actors adjust their framing to the framing channel (Bator and Cialdini, 2000). Previous studies demonstrate that actors have engaged in technology framing through various channels, such as the media or conferences, that require different approaches (Kaplan and Tripsas, 2008; Lampel, 2001). For example, it has been found that scientists adjust their framing when communicating with political constituents within and outside of science in order to achieve a high degree of resonance and garner public support for their activities (Frickel and Gross, 2005; Jasanoff, 1987).

\section{The role of materiality in the strategic framing of technologies}

While we have mounting evidence on the sociopolitical factors that shape framing, we know much less about how strategic framing of technologies is influenced by characteristics of the technologies themselves-i.e., their observable, material properties and their evolution over time. ${ }^{1}$ The literature

\footnotetext{
${ }^{1}$ It should be noted that in the literature there are different definitions of materiality. While some authors use the term to indicate that something is "material," i.e., has an important influence, we follow Leonardi (2012), who defined materiality as "[t]he arrangement of an artifact's physical and/or digital materials into particular forms that endure across differences in place and time and are important to users." In line with our study, this definition puts particular emphasis on the empirically observable physical matter and form of objects. Moreover, while Leonardi (2012) suggests that physical material, form, and function are stable in the short run (i.e., do not change from one moment to the other depending on fluid interpretations), they may well change over time as a result of technological change.
} 
stresses that credible framing requires actors to combine social and material elements into a coherent whole (Polkinghorne, 1988). Still, given that most theories on strategic, public framing originate in institutional entrepreneurship, social movements, and impression management, it is not surprising that sociopolitical variables have taken center stage. Existing frameworks in the field of impression management primarily study how actors use language to enhance their own image or legitimacy, rather than looking at technology. Frameworks rooted in institutional entrepreneurship and social movements have investigated how actors strategically frame technologies. However, similar to studies on impression management, studies in these fields do not explicitly discuss how material factors shape actors' framing strategies. As a result, even though Weick (1979) suggests that technologies reside in two intersecting arenas - the mental and the physical — in many studies framing appears to be largely decoupled from the physical world, becoming primarily a question of actors' skill in constructing reality (Garud et al., 2002; Kaplan, 2008).

Three literature streams that have explicitly considered the link between material and social variables are the literature on social construction of technology (Pinch and Bijker, 1984), technologyin-practice (Orlikowski, 2008) and sociomateriality (Orlikowski, 2007). Studies in these fields have investigated how social practices are entangled and co-evolve with material technologies to study how the social context affects the interpretation of technologies and how technologies shape organizational routines (Orlikowski, 2007; Orlikowski and Scott, 2008). In this context, authors have also demonstrated that organizational members use framing to shape the meaning of technologies (Leonardi, 2012). Thus far, however, this literature does not provide a theoretical framework describing how technology characteristics shape the detailed framing actors use in this negotiation. In fact, although the literature on social construction of technology explicitly considers material artefacts, authors have criticized its strong focus on social variables (Leonardi and Barley, 2010). The literature on sociomateriality explicitly assigns equal weight to material and social aspects 
(Orlikowski, 2007). Yet studies in this field mostly focus on collective sensemaking processes during technology implementation within organizations, thus providing limited insights into the role of framing and materiality in the context of technology competition and evolution (Leonardi, 2013; Orlikowski, 2007).

An additional stream that provides more detailed insights into the role of technology characteristics for strategic technology framing is the literature on the sociology of expectations (Borup et al., 2006; Garud et al., 2014). Studies in this field investigate how expectations, considered as "real-time representations of future technological situations and capabilities" (Borup et al., 2006, p. 286), are constructed and evolve. Regarding materiality, this stream has mainly explored how the verbal construction of expectations affects material reality (through the so-called "performativity of expectations"), rather than the impact of the material world on the construction of verbal accounts. Correspondingly, early work in this field stresses that "[n]ovel technologies and fundamental changes in scientific principle do not substantively pre-exist themselves" (Borup et al., 2006, p.285). However, later studies acknowledge that, even though framed expectations may not be true or false per se, different accounts may be more or less meaningful to stakeholders depending on their connection with data and ongoing developments (Van Lente, 2012).

In fact, authors in the field of sociology of expectations have highlighted that using framing to shape stakeholders' expectations involves a dilemma (Garud et al., 2014). Actors need to present stakeholders with comprehensive and plausible futures to gain legitimacy and induce them to invest resources. In doing so, however, they make commitments that fuel future disappointments (Ruef and Markard, 2010; Van Lente and Bakker, 2010). If actors frame technologies in a way that sets high expectations among stakeholders, they run the risk that developments in the material sphere will not live up to stakeholders' expectations. Particularly if material developments are easily observable, this may lead stakeholders to withdraw their support and can undermine the legitimacy, credibility, and 
reputation of the framing actor (Borup et al., 2006; Garud et al., 2014; Konrad, 2006; Rhee and Fiss, 2014). Vivid examples of how exaggerated expectations and resulting disappointments may significantly hurt actors can be found in the literature on technology hypes, which studies the drivers and dynamics of exaggerated claims around technologies (Brown, 2003; Ruef and Markard, 2010).

The fact that disappointments can significantly hurt the legitimacy and credibility of framing actors, raises the question of how exactly actors can construct narratives that promote technologies while accounting for those technologies' observable or potential future shortcomings. Studies in the field of the sociology of expectations suggest that actors weave together accounts of the past, present, and future to build credible expectations (Alkemade and Suurs, 2012; Brown and Michael, 2003); draw on metaphors and images (Nerlich and Halliday, 2007; Van Lente, 1993); include statements about the technology's performance, historical progress, path forward, and end targets (Bakker et al., 2012); and adjust their framing as changes in the material environment render previous claims noncredible (Bakker and Budde, 2012; Brown and Michael, 2003). In addition, in line with the literature on impression management, the literature shows that actors use modest or even negative statements in combination with positive framing to forestall future disappointments (Bakker, 2010; Berkhout, 2006; Moreira and Palladino, 2005; Tutton, 2011). For example, Gardner et al. (2015) describe how clinicians providing deep brain stimulation to children with movement disorders used a mix of optimistic and more ambivalent and modest visions of the future when communicating with patients, to avoid raising unrealistic expectations and hopes.

Despite these valuable insights, however, it currently remains unclear how the use of specific framing elements and tactics is related to the characteristics of the technology being framed, such as its maturity or evolution. In other words, we lack a more generalizable, systematic framework showing how actors tie their strategic technology framing to material technology characteristics to offer credible verbal accounts and avoid potential disappointments. Such a framework would help us 
understand the agency actors have in affecting others' beliefs and expectations of technologies. For example, to which extent do observable differences in technology characteristics lead to differences in the means of framing actors use when trying to influence expectations in their favor? Moreover, deepening our knowledge of the link between strategic framing and technologies may provide novel insights into the antecedents of technology hypes. For example, how can actors preempt disappointments resulting from a mismatch between stakeholders' expectations and material developments? And how do organizations create positive expectations and beliefs about technologies in the face of observable shortcomings? Understanding how framing patterns are linked to technological characteristics and evolution may provide first answers to these questions and help investors, consumers, and other observers spot exaggerated claims by firms developing novel technologies.

\section{METHOD}

Previous studies have not explicitly investigated how technology characteristics and evolution influence strategic technology framing. We therefore chose an inductive case-study methodology to explore the mechanisms in detail (Eisenhardt, 1989; Eisenhardt and Graebner, 2007; Weick, 2007). Case studies are particularly well suited for generating rich empirical descriptions when little theory exists.

\section{Research setting}

As is recommended for qualitative case studies, we followed the principle of theoretical sampling (Eisenhardt and Graebner, 2007; Yin, 2009). Specifically, investigating how technology characteristics shape the strategic framing of technologies, required us to find a setting characterized by (a) technologies that differ in their characteristics, and (b) technological uncertainty that induces actors pursuing the technologies to engage in framing to shape the expectations and beliefs of other 
stakeholders. Based on these criteria, we chose to investigate framing at the world's two largest research institutes working on solar photovoltaic ("PV") power: the National Renewable Energy Laboratory ("NREL") in Golden, USA, and the Fraunhofer Institute for Solar Energy Systems ("Fraunhofer ISE”) in Freiburg, Germany. Research institutes are particularly well suited to studying the strategic framing of technologies, since their core mission is to develop technologies. We selected these two research institutes for PV technologies, since (a) throughout the history of PV there has been considerable uncertainty about which of several competing PV technologies (if any) will dominate the market in the longer run; (b) the two research institutions strategically focused on competing PV technologies that differed in their characteristics; and (c) in the face of the technological uncertainty, organizational members have made extensive use of public framing in relation to the different PV technologies to influence the expectations of important stakeholders, such as funders, politicians, employees, or the general public.

Since the 1970s, several PV technologies, each with its own advantages and disadvantages, have vied for supremacy (Hoppmann et al., 2013). While the market has been dominated by waferbased crystalline silicon ("c-Si") technologies, there are two others with the potential to usurp c-Si: thin-film and third-generation PV (Bagnall and Boreland, 2008). Although these technologies have historically been considered competitors, since they all allow electricity to be generated from solar irradiation, it is still unclear whether one will dominate the market long-term. In fact, given that different applications favor different technology characteristics, it seems possible that the technologies continue to exist along-side each other in different market segments.

To produce PV modules from c-Si, silicon of high purity is drawn or cast into ingots, cut into wafers, processed into solar cells, and finally assembled into modules. In contrast, thin-film PVsuch as modules based on amorphous silicon (a-Si), copper indium gallium selenide (CIGS), and cadmium-telluride (CdTe) — and emerging PV—-such as nano, organic, or dye-sensitized PV—are 
produced using a highly automated process during which a very thin semiconductor layer is deposited on to a carrier such as glass.

Although NREL and Fraunhofer ISE pursue a similar mission of promoting renewable energy and energy efficiency through applied and basic research, developing technologies, and transferring knowledge to industry, they strategically focused on different, competing PV technologies. While NREL has put a strong focus on thin-film PV, Fraunhofer ISE focuses on c-Si PV. These differences in focus, together with strong uncertainty about which technologies (if any) would prevail in the longer run induced members of the two institutes to engage in framing that supported their respective choice. In our study, we focus on how the executives of NREL and Fraunhofer ISE framed technologies, since previous research indicates that top-level managers play a particularly important role in framing. ${ }^{2}$

As the temporal boundaries for our study, we chose the time from the organizations' inception to the end of 2013. NREL was founded in 1977 as the Solar Energy Research Institute (SERI) and designated a US national laboratory in 1991. Fraunhofer ISE was established in 1981. The fact that the thin-film and c-Si PV differ with regard to important technology characteristics and have evolved over time makes our setting ideally suited to study how technology characteristics shape patterns of executives' technology framing.

\section{Data collection}

We combined archival data from various sources with in-depth interview data. First, to understand the broader environment, technology characteristics, and the evolution of the institutes' technological focus, we collected data on technology performance over time, the institutes' scientific publications

\footnotetext{
${ }^{2}$ For our study, we defined executives broadly as all individuals holding a higher-level leadership position-comprising, for example, the institute directors and heads of department, as well as the leaders of special programs at NREL or Fraunhofer ISE.
} 
and patents, as well as executives' profiles. We obtained data on technology characteristics and evolution from the two industry magazines "Photon" and "PV News". We drew on the ISI Web of Science to download 3,916 and 1,559 scientific publications on solar PV by NREL and Fraunhofer ISE respectively, covering the years from their respective foundations until the end of $2013 .^{3}$ Moreover, we used Derwent Innovation to collect 353 patents filed by the two institutes to gain insights into their technological focus. Data on executives' background was collected from the institutes' websites and press articles.

Second, to measure framing, we collected archival documents containing direct statements by executives of both NREL and Fraunhofer ISE. For this purpose, we screened the 5,475 scientific articles published by both organizations, searched their annual reports, and used Factiva to collect 322 press articles containing quotes from their executives. ${ }^{4}$ We chose to collect statements from scientific and media sources, since previous research indicates that framing may differ depending on the framing channel and audience. Since we were aware that there was (and is) considerable uncertainty about the advantages and disadvantages of different PV technologies, we expected executives to use framing to argue for or against different PV technologies. Therefore, from all sources, we extracted a total of 287 statements in which executives publicly described and assessed the alternative PV technologies. To account for the possibility that differences in the assessment of

\footnotetext{
${ }^{3}$ The ISI Web of Knowledge only covers a limited range of journals. However, given that the majority of journals in which the two organizations have published are contained in the database, it serves as a reliable source to compare the technological focus of the two organizations over time. To obtain scientific articles on solar PV by researchers at NREL, we searched for the topic "solar* OR photovoltaic*", while simultaneously limiting the address to "Golden AND (Solar* or Nat*)". Using these search terms ensured that we were able to find articles by NREL published under its former name "Solar Energy Research Institute" as well as different abbreviations used for its current name "National Renewable Energy Laboratory." To obtain scientific articles on solar PV by researchers at Fraunhofer ISE, we altered the address to "Fraunhofer AND Solar* AND Freiburg". This search string for Fraunhofer ISE excluded all publications made by Fraunhofer Institutes other than Fraunhofer ISE in Freiburg, Germany.

${ }^{4}$ To identify statements that indicated the organizational members' stance toward different PV technologies, we used a search string consisting of the names of the executives (in different variations) in combination with the name of the research institute. NREL executives included in this search were Dan Arvizu, Howard Branz, Charley Gay, Denis Hayes, Harold Hubbard, Lawrence Kazmerski, Paul Rappaport, Ryne Raffaelle, Duane Sunderman, Richard Truly, Gregory Wilson, and Kenneth Zweibel. Executives from Fraunhofer ISE covered in the search were Andreas Bett, Stefan Glunz, Adolf Goetzberger, Joachim Luther, Roland Schindler, Gerhard Stryi-Hipp, Eicke Weber, Gerhard Willeke, and Volker Wittwer.
} 
technologies resulted from differences in the assessment of the broader category of PV technology in general, we also included statements on PV overall in this step.

Finally, we conducted interviews with 16 current and former executives of NREL and Fraunhofer ISE. Interviewees from Fraunhofer ISE included the director, the two former directors (including the founder), the heads of the research departments for solar cells and technologies and solar cell development and characterization, and the coordinator of PV research, as well as four directors of two subsidiaries: the Fraunhofer Center for Silicon Photovoltaics and the Fraunhofer Center for Sustainable Energy Systems in Cambridge, USA. At NREL, we interviewed the current director, the current and one former director of NREL's National Center for Photovoltaic, the Deputy Lab Director of Strategic Programs and Partnerships, the Director of the Center for Chemical and Materials Science, and a Senior Analyst in the Strategic Energy Analysis Center. Interviews were semi-structured and typically lasted an hour. To enhance reliability, interviews were transcribed and saved in a central database (Gibbert et al., 2008; Yin, 2009). Table 1 summarizes our data sources.

TABLE 1: Data sources

\begin{tabular}{lll}
\hline \multirow{2}{*}{ Data source } & \multicolumn{2}{c}{ Number of sources } \\
\cline { 2 - 3 } & NREL & Fraunhofer ISE \\
\hline Budget reports of political sponsoring bodies & 50 & 11 \\
\hline Annual reports & 24 & 33 \\
\hline Press articles & 418 & 241 \\
\hline Scientific publications & 3,916 & 1,559 \\
\hline Interviews with current and former executives & 6 & 10 \\
\hline
\end{tabular}

\section{Data analysis}

Our data analysis consisted of four phases. In the first phase, as part of our sample selection, we reviewed background information on NREL and Fraunhofer ISE as well as press articles that 
included statements by their executives. An initial round of open coding revealed striking differences in the technological focus and assessment of PV technologies across the two organizations. Therefore, we conducted a first round of interviews with (former) executives to better understand the history of the research institutes, their technological choice, and their assessment of technologies. These interviews confirmed our initial observations. Based on our emerging understanding of core constructs, we collected detailed data on technology characteristics, framing, technological foci, and executives' backgrounds (see previous section).

In the second phase, we used another round of coding to generate detailed insights into executives' technology framing, based on the 287 direct statements gathered. To this end, we listed all executive statements and in each case coded the technology executives referred to (c-Si, thin-film, or PV in general) and whether the assessment was positive or negative (Hallahan, 1999). To investigate how executives used framing, we first experimented with coding based on concepts from the literature, such as prognostic, diagnostic, and motivational framing (Benford, 1993; Kaplan, 2008). However, no existing framework or taxonomy explicitly took account of material technology characteristics. To be able to fully capture material factors, we therefore turned to inductive coding to develop our own categories (Gioia et al., 2013; Langley and Abdallah, 2011).

First-order coding revealed that technology performance in terms of cost, conversion efficiency, material use, knowledge, and market share was a key theme. However, executives differed in terms of whether they referred to performance in the indefinite future, definite future, present, or past tense. Based on these observations, in a highly iterative process and using axial coding across the statements, we developed four second-order categories - potential, prospect, performance, and progress - that we labeled framing dimensions.

We also noticed differences in how executives used these dimensions. All statements contained at least one dimension, but while they were used singly in roughly half of cases, executives 
often skillfully combined them. To shed more light on this, we investigated statements' syntactic and semantic structure (Fillmore, 1976; Pan and Kosicki, 1993), which yielded three additional secondorder categories - conclusion, conditioning, and concession - that we group into the category of framing tactics. Drawing on the concepts of framing dimensions and framing tactics, all statements were then formally and independently coded by two researchers, one of whom had not been involved in the research project, to develop a summary of technology framing for both organizations. ${ }^{5}$

In the third phase, we conducted a second round of interviews to uncover the antecedents of framing patterns (Borah, 2011). Presenting the results of our analysis to interviewees, we asked them to explain the differences in framing, both across the two organizations and over time. Questions probed differences in the use of framing dimensions and framing tactics. Moreover, we explicitly asked interviewees to reflect on how their framing was related to their organizations' technological focus, technology characteristics and evolution, and stakeholders. The interviews were subsequently transcribed and coded to assign the antecedents to our previously established categories. To glean additional insights into the role that technology characteristics played for framing, we also developed detailed timelines of how the performance of alternative PV technologies in terms of cost, conversion efficiency, material use, knowledge, and market share had developed over time.

In the fourth phase, which overlapped with phases two and three, we used pattern matching to build a parsimonious and robust framework detailing how technology characteristics affected executives' framing of PV technologies (Yin, 2009). For this purpose, we used both cross-case and within-case comparisons to uncover relationships between our framing categories on one hand and the characteristics of the organizations, environment, technologies, and target audience on the other (Eisenhardt, 1989; Eisenhardt and Graebner, 2007). To establish these links, we drew heavily on our

\footnotetext{
${ }^{5}$ The intercoder reliability (Cohen's Kappa) was 78.2\%, indicating excellent reliability (Fleiss et al., 2003).
} 
analyses of the organizations' technological focus and the drivers of framing identified in the interviews. As recommended by Gibbert et al. (2008), we moved iteratively back and forth between our data and the literature to enhance the internal validity of the framework. We triangulated between quantitative and qualitative data sources. Moreover, we constantly challenged the external validity of the framework by discussing its application to other empirical cases (Gibbert et al., 2008). The iterative process was concluded when we were confident that the framework accurately captured both the differences and dynamics in framing we observed (Eisenhardt, 1989).

\section{FINDINGS}

Below, we present our findings on how technology characteristics influenced the strategic framing of technologies by executives at NREL and Fraunhofer ISE. We first summarize the two organizations' technological foci and uncertainty about the technological evolution in PV. Subsequently, we show how, faced with this uncertainty, executives engaged in strategic technology framing. We describe the four dimensions and three tactics of framing, and explain how differences in their use across organizations and time are driven by technology characteristics. Finally, we present our theoretical framework. We use the codes D1-D48 and I1-I16 to reference selected archival documents and our interviewees respectively (list of documents available on request).

\section{Technology focus and uncertainty of NREL and Fraunhofer ISE}

From their foundation, NREL and Fraunhofer ISE differed considerably with regard to the PV technologies they pursued. NREL maintained a strong focus on thin-film PV, while Fraunhofer ISE emphasized c-Si PV. We found that this divergence was largely due to differences in funding sources. Throughout its history, NREL has "almost exclusively been funded by the US Department of Energy (DOE)" (I11), which, in turn, is allocated an annual budget through the US Congress (D1-D10). Since the DOE put a strong emphasis on funding thin-film PV, NREL focused on this technology, 
and built specific capabilities around it. In the words of an executive, "they [the DOE] have chosen $[\ldots]$ to put the money into thin-film. That's why NREL did so much thin-film" (I11). Only in recent years did NREL also step up its work on c-Si PV (I6, I11).

Fraunhofer ISE, on the other hand, "put a strong emphasis on crystalline silicon" (I10) because it is a subsidiary organization of the Fraunhofer Society. The Society's central mission is to foster applied research of direct value to the private sector. Therefore, apart from modest base funding of around $10 \%$, it requires its institutes to competitively acquire all funding from third parties, with at least $25 \%$ coming directly from industry. Fraunhofer ISE responded to this by strategically focusing on research in c-Si PV, "where there is a direct interest of the industry" (1I8).

Although NREL and Fraunhofer ISE focused on specific PV technologies throughout the study period, there was considerable uncertainty in the industry about whether c-Si or thin-film would lead the market in the long run - an uncertainty that persists to this day. As an NREL executive stressed, the issue was hotly contested at the DOE: "There has been kind of a competition, maybe a little dilemma as to how much focus to put on [crystalline] silicon versus the other technologies" (I11, I16). Similar indications that neither c-Si nor thin-film PV was perceived as a safe bet came from key Fraunhofer ISE funders. For example, in its 2008 annual report, Q-Cells, which had funded collaborative research at Fraunhofer ISE on c-Si PV, stated that "thin-film modules are gaining ground rapidly," inducing it to invest in various thin-film technologies (D12). In a similar vein, the German Ministry for the Environment stated in its 2005 annual report that it believed in a "renaissance" of thin-film, and that "experts see good chances for a breakthrough" (D11).

This funder uncertainty was crucial for NREL and Fraunhofer ISE, since both depended heavily on research funding from established channels. Historically, high overheads prevented NREL from gaining significant funds directly from industry, leaving it heavily reliant on DOE funding. 
Similarly, being part of the Fraunhofer Society required Fraunhofer ISE to acquire much of its funding from industry to retain its license to operate.

\section{Strategic technology framing}

How did the executives of NREL and Fraunhofer ISE react to this uncertainty over PV? Our findings suggest that, in line with expectations, they made systematic use of technology framing to paint a picture that favored their own organizations. On the one hand, this was important to attract new funders. For example, as one executive emphasized, promoting the organization's own technology was "of course a strategic question. [...] It is about what you are working on and what you get your funding for" (I9). On the other hand, it also reassured past funders that their money had been wisely invested, so they would fund additional projects. In the words of one executive:

Well, you can't get away from the fact that these institutes constantly have to fund-raise for their activities and they need to give their supporters [...] the sense that they are investing in the right things. [...] If you say, "Hey, yes, I'm taking your money to develop this technology," but then you turn around and go to conferences and say, "This technology is no good, that other one is much better, "I think that is hard to do. (I3)

Both NREL and Fraunhofer ISE therefore engaged in framing to reassure their funders and secure additional funding. Indeed, interviewees reported that their expertise helped both institutes to influence the discourse on PV. For example, although the DOE "wants NREL to compete alongside of all different universities and other national labs" (I4), it also "relies heavily on NREL to develop their energy agenda. They heavily rely on the experts to understand what the cost roadmaps are, what the prospects of a technology are" (I3). As a result, NREL served as "a strategic advisor to the DOE" (I11) and has "been able to advise [the DOE] how the funds are distributed among conversion technologies" (I13).

Similarly, executives at Fraunhofer ISE reported that they "frequently participated" in expert solicitations (I12), were "active in various political advisory boards" and company advisory boards 
(I12), and "talked to politicians about which PV technologies make most sense" (I10). Moreover, when the industry emerged in 1997, "Fraunhofer ISE intensified its activities in industry-oriented technology marketing" (D74) by implementing a support function for "public relations and marketing" (I1). All these activities allowed executives at both institutes to show their own technologies in the best light to secure and further grow funding in times of technological uncertainty.

\section{Framing dimensions}

But how did executives frame the different technologies? We find that to positively portray their own PV technology in times of uncertainty, executives referred to different points in time - namely, the indefinite future, definite future, present, or past. This suggested four dimensions of technology framing, i.e. core temporal elements that actors use to strategically frame beliefs and expectations about the technology: potential, prospect, performance, and progress.

First, executives spoke about the indefinite future to highlight the potential of a technology, i.e. its hypothetical performance (e.g., in terms of cost, conversion efficiency, quality, material intensity, market share) at an undefined point in the future. For example, Kenneth Zweibel, manager of the polycrystalline thin-films program at NREL, opined in 1987 that " $[\mathrm{t}]$ hin films can absorb sunlight in a thickness that is 100 times smaller than previous technology. It's potentially 100 times cheaper for materials and manufacturing costs" (D13). Second, executives drew on rhetorical devices to convey a particular impression of the performance of a technology at a specific point in the future. As an example of this prospect framing, Eicke Weber, director of Fraunhofer ISE, predicted in 2007 that "the market share of crystalline silicon will be at $80 \%$ in 10 years" (D14). Third, executives also used language to underline the present performance of technologies. As an example of this, Kenneth Zweibel noted in 1992 that "the development of cadmium telluride (CdTe) [thin-film] photovoltaics has reached a stage where it can be considered a leading candidate for cost-competitive PV electricity generation" (D15). Finally, executives used rhetoric to draw attention to changes in performance 
relative to some time in the past. As an example of such progress framing, Jack Stone, the director of NREL's photovoltaic division, stated in 1984 that "the extraordinary progress in [...] the amorphous silicon thin film technology is indeed a high technology Cinderella story” (D16).

Figure 1 illustrates the different dimensions along which actors can shape expectations and beliefs about technologies, and how expectations can be framed by referring to different points in their life-cycles. Table 2 summarizes the definition of the framing dimension constructs and provides further examples. Table 3, finally, shows how far the two organizations drew on the dimensions when positively and negatively framing thin-film PV, c-Si PV, and PV in general.

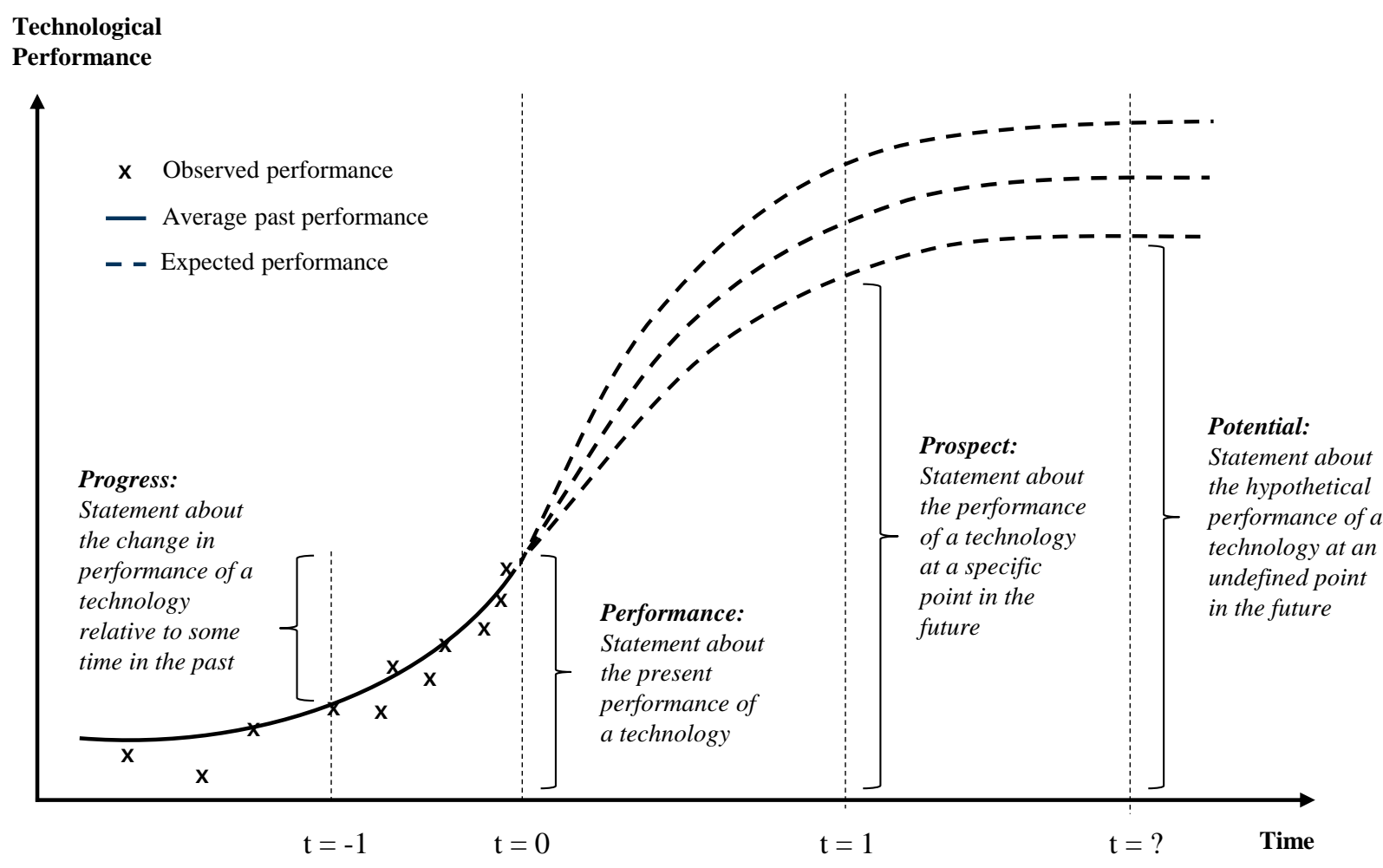

FIGURE 1: Graphical illustration of dimensions that can be used to frame performance of technologies to shape the beliefs and expectations of stakeholders 
TABLE 2: Framing dimensions

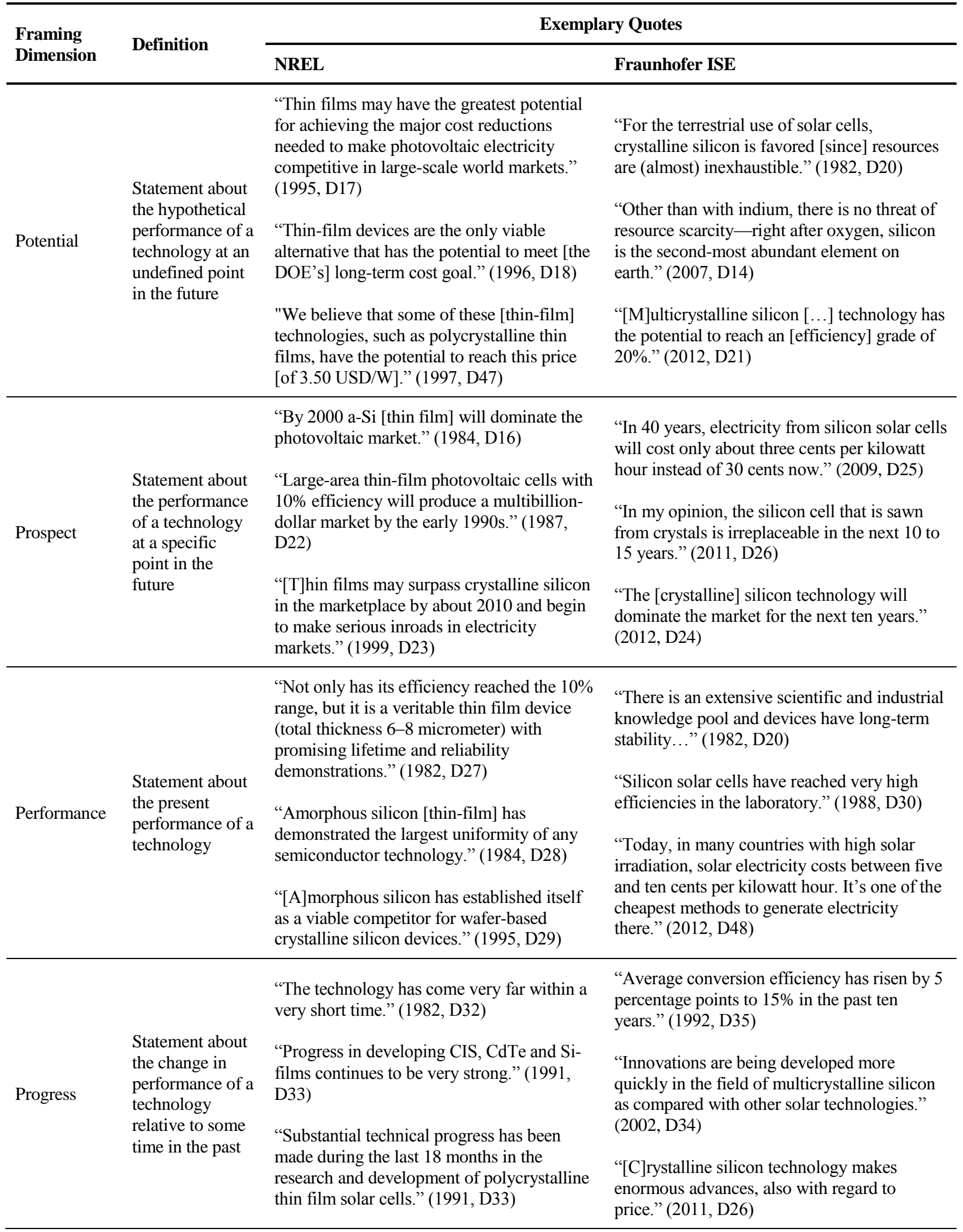


TABLE 3: Use of framing dimensions by NREL and Fraunhofer ISE with regard to thin-film PV, c-Si PV, and PV overall

\begin{tabular}{|c|c|c|c|c|c|c|c|c|c|c|c|c|c|}
\hline \multirow{2}{*}{$\begin{array}{l}\text { Organi- } \\
\text { zation }\end{array}$} & \multirow{2}{*}{$\begin{array}{l}\text { Framing } \\
\text { dimension }\end{array}$} & \multicolumn{4}{|c|}{ Positive framing } & \multicolumn{4}{|c|}{ Negative framing } & \multicolumn{4}{|c|}{ Net framing } \\
\hline & & Thin-film & C-Si & & PV overall & Thin-film & C-Si & & PV overall & Thin-film & C-Si & & V overall \\
\hline \multirow[t]{5}{*}{ NREL } & Potential & 76 & & 8 & 8 & 0 & & 10 & 0 & 76 & & -2 & 8 \\
\hline & Prospect & 31 & & 7 & 4 & 4 & & 3 & 4 & 27 & & 4 & 0 \\
\hline & Performance & 44 & & 14 & 6 & 22 & & 16 & 14 & 22 & & -2 & -8 \\
\hline & Progress & 41 & & 5 & 18 & 3 & & 3 & 0 & 38 & & 2 & 18 \\
\hline & Sum & 192 & & 34 & 36 & 29 & & 32 & 18 & 163 & & 2 & 18 \\
\hline \multirow{5}{*}{$\begin{array}{l}\text { Fraunhofer } \\
\text { ISE }\end{array}$} & Potential & 6 & & 15 & 22 & 2 & & 2 & 0 & 4 & + & 13 & 22 \\
\hline & Prospect & 5 & & 16 & 53 & 4 & & 0 & 1 & 1 & t. & 16 & 52 \\
\hline & Performance & 4 & & 22 & 22 & 5 & & 5 & 9 & -1 & & 17 & 13 \\
\hline & Progress & 1 & & 18 & 48 & 1 & & 0 & 0 & 0 & ) & 18 & 48 \\
\hline & Sum & 16 & & 71 & 145 & 12 & & 7 & 10 & 4 & 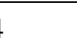 & 64 & 135 \\
\hline
\end{tabular}

Figures indicate how many times a specific framing dimension is used in the 287 statements in which executives of NREL and Fraunhofer ISE publicly described and assessed the alternative PV technologies. Darker shading denotes higher figures. Net framing is calculated as the difference between positive and negative framing

We found instances of the four dimensions of technology framing in all 287 statements we collected. Interestingly, however, the frequency with which a specific dimension was used differed markedly across the organizations. Table 3 shows that, as expected, executives of both organizations showed a strong tendency to favor their organization's "own” technology over alternatives. Also, in line with the idea that c-Si PV was the dominant technology, Fraunhofer ISE did not just positively frame c-Si PV specifically, but also PV overall.

Interestingly, however, when framing the PV technologies, executives at NREL focused on the dimension of potential, whereas Fraunhofer executives focused on performance (to frame c-Si PV) and prospect and progress (to frame PV overall). Throughout their history, executives at NREL stressed the major potential of thin-film for generating low-cost electricity, while putting less emphasis on its performance, progress, or prospects. For example, in 1999, when c-Si had dominated the market for several decades, an NREL executive still stated that "[ $\mathrm{t}]$ here can be no doubt that ultimately thin-film technologies should offer the best cost/performance prospects" (1999, D19). 
Fraunhofer ISE, in contrast, relied much less on potential framing but placed a strong emphasis on present technology performance. For example, in 1995, founder Adolf Goetzberger expressed that "[u]p to today, no alternative to crystalline silicon [...] has been found that has proven itself in praxis" (D31). Below, we provide evidence on the factors driving the choice of framing dimensions. We show that choices hinged on the demands of key stakeholders as a sociopolitical factor, but were also shaped by the maturity of the technology being framed as a technology characteristic.

\section{Demands of key stakeholders as a driver of framing dimensions}

NREL predominantly relied on potential framing of thin-film PV, while Fraunhofer ISE primarily framed c-Si PV in terms of performance. In line with the literature, this pattern can be partly explained by the organizations' aim of making their frames resonate with primary stakeholders. NREL's primary funder, the DOE, favors more radical research distant to the market, to avoid biasing market competition. As one executive stressed, this made a stronger emphasis on potential almost a requirement for NREL when it came to seeking funding:

In the US landscape, if you write a proposal to a government institution, you have to make much bolder claims about the potential, than I believe you have to do in Germany. You also have to make bolder claims of what you will actually be achieving. It has to be very ambitious, has to have very high potential, and it is very hard to get any work that makes an incremental improvement funded in the US [...]. [T] he funding agencies will say that if it's an incremental improvement, then industry can do it itself. (I3)

In contrast, Fraunhofer ISE acquired much of its funding from industrial partners such as producers of PV cells, modules, and manufacturing equipment. Industry, however, was less interested in the long-term potential of a technology than its short-term performance. According to an executive, Fraunhofer ISE therefore found it most effective to frame expectations accordingly:

As a Fraunhofer institute, we need to conduct research close to the market. We want to do research close to the industry, together with the industry. This means that in terms of framing, what is of greatest interest to us is how to improve the current performance, the progress. That's what we look at very closely. (II)

\section{Technology maturity as a driver of framing dimensions}


While the choice of framing dimensions was driven by the institutes' audience, we find that this sociopolitical factor alone was insufficient to explain executives' framing. Choosing framing dimensions that resonate with the audience is important to realize short-term benefit. Yet claims of "high performance" or "high potential" can quickly be perceived as non-credible if they do not reflect empirically observable characteristics. Indeed, although methods for evaluating PV technologies have been refined over time, two core evaluation criteria-conversion efficiency and cost of electricity — were clear and measurable from the outset. We therefore noted that the choice of framing dimensions by NREL and Fraunhofer ISE was driven not only by the need for resonance, but also by material technology characteristics. Specifically, we found that which dimension executives chose to frame their own technology depended heavily on its maturity.

The fact that c-Si PV had been invented as far back as 1954 gave it a head start compared to thin-film, which only dated from the 1970s. By drawing on silicon as the main material, c-Si PV could build upon decade-long experience in semiconductors, implying that many of its material properties were well understood. Moreover, although silicon was not an optimal material when it came to light absorption, c-Si PV—due to its early inception—consistently offered higher electrical conversion efficiencies than thin-film PV (up to $20 \%$ for commercially available modules in 2013). Indeed, from day one, c-Si PV was used in commercial applications such as extra-terrestrial satellites, telecommunication towers, oil platforms, and larger-scale power applications. The commercial use of c-Si PV helped researchers and industry gather experience in the field, increase its performance, and reduce costs through mass manufacturing. A major drawback of c-Si PV, however, lay in its high material intensity, which primarily resulted from the fact that to manufacture c-Si PV modules, silicon ingots had to be cut into wafers, which wasted a great deal of material and also required a minimum wafer thickness to prevent breakages. Since the high material intensity was connected with 
high material costs, for many years it was unclear whether c-Si PV had the physical potential to reach a cost level at which it could compete with conventional power technologies such as coal or nuclear.

The high material intensity of c-Si PV and related material costs led to the development of thin-film PV as an alternative technology in the 1970s. To produce it, a thin layer of semiconductor material is deposited on to a substrate such as glass. Hence, thin-film requires much less semiconductor material, holding out the possibility of lower costs for electricity generation in the future. Although thin-film allows the use of more expensive semiconductor material with better physical absorption properties, producing thin-film modules at a size that could power homes for a long time proved difficult, such that thin-film modules remained unreliable and were used only in niche applications, such as calculators. Indeed, as Figure 2 shows, while for the same amount of deployment thin-film showed significantly lower costs in EUR/Watt peak than c-Si PV, it always lagged behind c-Si PV in terms of deployment, such that it could not reduce costs far enough to make up for its disadvantage in conversion efficiency and reliability. Table 4 shows that c-Si PV does indeed show a higher technological maturity than thin-film along different performance dimensions.

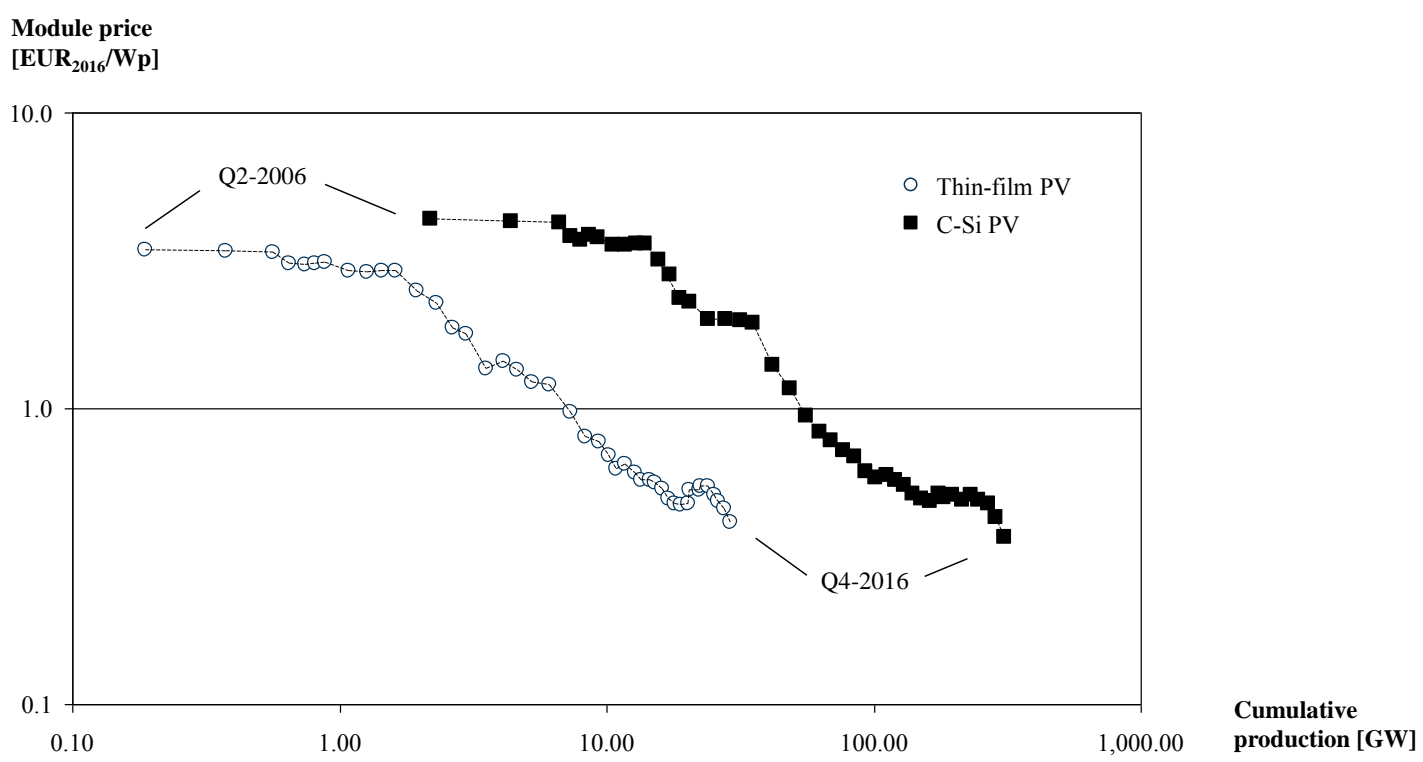

FIGURE 2: Cumulative production and learning curves of c-Si PV and thin-film PV (Fraunhofer ISE, 2017) 
TABLE 4: Indicators showing differences in technological maturity of c-Si PV and thin-film PV

\begin{tabular}{lll}
\hline Category & C-Si PV & Thin-film PV \\
\hline Commercial conversion efficiencies (2013) & $14-20 \%$ & $8-15 \%$ \\
\hline Cost per Watt peak (2013) & $0.59 \mathrm{EUR} / \mathrm{Wp}$ & $0.60 \mathrm{EUR} / \mathrm{Wp}$ \\
\hline Global market size (2013) & $112 \mathrm{GW}$ & $13 \mathrm{GW}$ \\
\hline Global market share (2013) & $91 \%$ & $9 \%$ \\
\hline
\end{tabular}

These differences in technology maturity help explain the differences in framing patterns across NREL and Fraunhofer ISE. By focusing on thin-film PV, NREL was pursuing an immature technology with uncertain performance characteristics that required continuous major investment to advance to a stage where it could compete with the dominant c-Si PV. As an executive noted, thinfilm had "disadvantages, for example with regard to reliability, and that we cannot control the processes very well" (I12). As a result, even if key stakeholders had required NREL to stress performance, the observable properties of thin-film PV would not have allowed executives to frame the technology this way. Instead, in line with the idea that thin-film offered potentially lower costs in the future, executives shifted their framing toward potential:

Thin-film is disruptive, novel, and therefore you also have more potential. [...] Therefore, you have to shift [your framing] to the future, to the potential. (II)

In comparison, the performance characteristics for c-Si PV were much more certain, such that the technology evolved along a more incremental path that allowed executives to be more confident in forecasting developments (e.g., using learning curves). Consequently, the higher maturity of c-Si allowed executives at Fraunhofer ISE to draw more heavily on performance framing to argue that potential thin-film breakthroughs were both unnecessary and unlikely in any case:

C-Si technology simply has a certain stability, since it is the technology with the largest market share. I believe that therefore you put more emphasis on performance. Potential has always been the strength of thin-film. (I15) 
In sum, reflecting the differences in technological maturity and hence actual performance, executives in both organizations strongly focused on those framing dimensions that were most favorable for their own technology. Doing so allowed them to credibly display their own technology in a favorable way — even though the technology suffered from significant shortcomings in other dimensions. As an executive we interviewed stressed, this framing, in turn, enhanced the possibility of acquiring funds from external stakeholders:

So it is very obvious that this has to do with the framing, with the relative importance people assign to potential versus actual performance. [...] You know, all these institutes, they are permanently in a state of rallying support for their activities. So obviously, there may be very conscious, let's say, "positioning thoughts" behind that. (I3)

Table A1 in Appendix A provides additional evidence for the influence of stakeholder demand and technology maturity on the use of framing dimensions.

\section{Framing tactics}

As well as using framing dimensions individually, in about half of the statements executives combined the different dimensions. We identified three patterns of logical combinations, which we label framing tactics. First, executives used what we label conclusion, i.e. logically linking dimensions by making claims about cause and effect. For example, Tom Surek, manager of NREL's PV Program, expressed in 2005 that "[t]hin-film technologies have the potential for substantial cost advantage versus wafer-based c-Si because of factors such as lower material use (due to direct bandgaps), fewer processing steps, and simpler manufacturing technology for large-area modules" (D36). Here, performance framing is used to derive conclusions about the potential of thin-film PV.

The second tactic was to position one dimension as the condition for another, a tactic we label conditioning. As an example of this tactic, Eicke Weber, director of Fraunhofer ISE, suggested in 2012 that "if prices continue to fall, self-produced solar electricity from people's own rooftops will 
soon be cheaper than the 26 cents per kilowatt hour from the electric utility" (D37). In this statement, he describes the prospect of solar electricity as being conditional on continued progress.

Finally, executives combined different framing dimensions such that a technology's shortcomings in one dimension were offset by its strengths in another, a tactic we term concession. For example, Adolf Goetzberger, a director of Fraunhofer ISE, noted in 2000 that "in spite of its complicated manufacture and the high cost, crystalline silicon still dominates the market today and probably will continue to do so in the immediate future" (D38). In this statement, he conceded c-Si PV's shortcomings in performance while still insisting on its positive prospects.

Table 5 summarizes the definitions of framing tactics we observed and provides additional exemplary statements. Similar to the use of framing dimensions, we find that executives systematically used the different tactics to positively influence stakeholders' expectations and beliefs about technologies. In the following, we first show that, in line with the literature, the use of framing tactics was driven by the framing channel as a sociopolitical factor. Subsequently, we show that, in addition, the choice of framing tactics was shaped by the material evolution of the technology.

\section{Framing channel as a driver of framing tactics}

Using conclusion, conditioning, and concession allows the four framing dimensions to be combined in ways that can lead to very different messages. In line with the literature, executives therefore reported that they systematically adjusted tactics according to the framing channel, i.e., the medium through which they communicated with stakeholders. For example, our interviewees explained that their choice of conclusion, conditioning, or concession was contingent on whether they had to frame technologies at conferences and in scientific papers, or in press interviews. As one executive reported, conferences required a stronger use of conditioning and concessions:

When I gave presentations, I always had pros and cons [concession] on my slides. For example, silicon has the disadvantage of being an indirect semiconductor, which means you 


\section{require relatively thick layers to absorb sunlight [...], so it depends on the cost of the material}

[conditioning]. (I6)

TABLE 5: Framing tactics

\begin{tabular}{|c|c|c|c|}
\hline \multirow{2}{*}{$\begin{array}{l}\text { Framing } \\
\text { Tactic }\end{array}$} & \multirow{2}{*}{ Definition } & \multicolumn{2}{|c|}{ Exemplary Quotes } \\
\hline & & NREL & Fraunhofer ISE \\
\hline Conclusion & $\begin{array}{l}\text { Linking } \\
\text { dimensions by } \\
\text { making claims } \\
\text { about cause } \\
\text { and effect }\end{array}$ & $\begin{array}{l}\text { Progress leads to Prospect: } \\
\text { "Improvements in materials, processing, and } \\
\text { cell fabrication for a new generation of } \\
\text { photovoltaic [thin-film] technologies continue } \\
\text { to result in efficiency gains. Steady and } \\
\text { dramatic advances are expected to continue } \\
\text { during this decade." (1989, D40) } \\
\text { Performance leads to Potential: } \\
\text { "Thin films are about } 30 \text { times thinner than } \\
\text { photovoltaics produced using conventional } \\
\text { wafer silicon technology and are also easier to } \\
\text { manufacture. These advantages could make } \\
\text { thin film photovoltaics much less expensive, } \\
\text { opening huge global markets." (1995, D39) }\end{array}$ & $\begin{array}{l}\text { Progress leads to Prospect: } \\
\text { "The vision is that even in the year } 2010 \text { and } \\
\text { beyond the main workhorse for PV power } \\
\text { generation will still be the crystalline silicon } \\
\text { wafer solar cell [...]. This vision is supported } \\
\text { by the fact that in the last } 15 \text { years the global } \\
\text { market share of crystalline silicon has steadily } \\
\text { increased at the expense of the a-Si thin film } \\
\text { technology." (2002, D34) } \\
\text { Potential leads to Prospect: } \\
\text { "The market share of crystalline silicon will } \\
\text { still be at } 80 \% \text { in } 10 \text { years. This is because, } \\
\text { other than with indium, there is no threat of } \\
\text { resource scarcity-right after oxygen, silicon is } \\
\text { the second-most abundant element on earth." } \\
\text { (2007, D14) }\end{array}$ \\
\hline Conditioning & $\begin{array}{l}\text { Linking } \\
\text { dimensions by } \\
\text { positioning one } \\
\text { dimension as } \\
\text { the condition } \\
\text { for another }\end{array}$ & $\begin{array}{l}\text { Performance as condition for Potential: } \\
\text { "If researchers can overcome nagging } \\
\text { manufacturing and marketing problems, new } \\
\text { devices could produce power for less than } \\
\$ 0.50 \text { per watt, low enough to make the cost of } \\
\text { PV-generated electricity competitive with gas } \\
\text { generators." (1996, D41) } \\
\text { Progress as condition for Prospect: } \\
\text { "With continued success, thin films may } \\
\text { surpass crystalline silicon in the marketplace by } \\
\text { about } 2010 \text { and begin to make serious inroads } \\
\text { in electricity markets." (1999, D23) }\end{array}$ & $\begin{array}{l}\text { Prospect as condition for Potential: } \\
\text { "It will take at least five years until one of the } \\
\text { new [thin-film] technologies will have a } \\
\text { significant market share. If it takes more than } \\
10 \text { years, it will be impossible to catch up to the } \\
\text { progressing silicon technology." (1995, D42) } \\
\text { Performance as condition for Prospect: } \\
\text { "Should-a second scenario-one of the new } \\
\text { technologies be successful, a market growth } \\
\text { rate of } 30 \% \text { can be expected." (1995, D42) }\end{array}$ \\
\hline Concession & $\begin{array}{l}\text { Linking } \\
\text { dimensions by } \\
\text { offsetting } \\
\text { shortcomings } \\
\text { in one } \\
\text { dimension by } \\
\text { strengths in } \\
\text { another }\end{array}$ & $\begin{array}{l}\text { Performance despite Performance of alternative } \\
\text { technology: } \\
\text { "The solar cells highest in efficiency are made } \\
\text { of single crystal silicon, but thin film devices } \\
\text { use a lot less material and cost about a fifth or a } \\
\text { tenth as much to make." (1995, D43) } \\
\text { Potential despite Progress in alternative } \\
\text { technology: } \\
\text { "Although crystalline Si PV manufacturing is } \\
\text { still experiencing an exponential growth pattern } \\
\text { in } 1999, \text { there can be no doubt that ultimately } \\
\text { thin-film technologies should offer the best } \\
\text { cost/performance prospects." (1999, D19) }\end{array}$ & $\begin{array}{l}\text { Performance and Prospect despite lack of } \\
\text { Potential: } \\
\text { "Although crystalline silicon is not the optimal } \\
\text { material from a solid-state physics point of } \\
\text { view, it dominates the market and will continue } \\
\text { to do so for the next 5-10 years." (1995, D42) } \\
\text { Performance despite Progress in alternative } \\
\text { technology: } \\
\text { "Despite the development potential of thin-film, } \\
\text { wafer-based silicon solar cells have a future, } \\
\text { since their long-term stability is beyond } \\
\text { question and their efficiency can be improved } \\
\text { with little effort." (2008, D44) }\end{array}$ \\
\hline
\end{tabular}


Conversely, talking to the press, according to our interviewees, required messages to be conveyed in simpler terms, using less conditioning and more conclusions. As one Fraunhofer executive put it, framing newsworthy messages "requires more simplification. You can call it marketing, but it needs to be simplified. And you need to leave the if-then statements out" (I1).

\section{Technology evolution as a driver of framing tactics}

While our interviewees stressed the importance of politically adjusting framing tactics in line with the channel, shoehorning tactics into framing channels runs the risk of content diverging from material observations, which may undermine the framing actor's legitimacy. For example, as one executive observed, using less conditioning in the press "raises the risk that part of the sentence is interpreted negatively, even though it wasn't meant that way" (I1). Therefore, we find that framing tactics are also driven by observable material developments. In particular, framing tactics followed the technological evolution, i.e. actual progress in developing the organization's technology.

While throughout the period of investigation, c-Si PV outperformed thin-film with regard to conversion efficiencies, reliability, and market share, neither technology developed in a linear way. Instead, at several points, both technologies met bottlenecks and setbacks that seemed to favor their rival. For example, Figure 3 shows the development of record conversion efficiencies of c-Si PV and thin-film PV, as well as the market share of thin-film PV. It shows that the conversion efficiencies of neither technology rose uniformly; instead, they experienced periods of strong growth and stagnation. Similarly, the market share of thin-film fluctuated over time. In the 1980s, thin-film PV began to be used in portable electronics such as calculators, rapidly rising to a market share of $32 \%$ by 1988 . In the 1990s, however, c-Si regained market share, to the extent that by 2004 thin-film only made up around $4 \%$ of the market. Then, a bottleneck in the supply of industrial-grade silicon in c-Si PV pushed thin-film's share back up to more than 17\% in 2010, before it receded to 9\% in 2013 . 


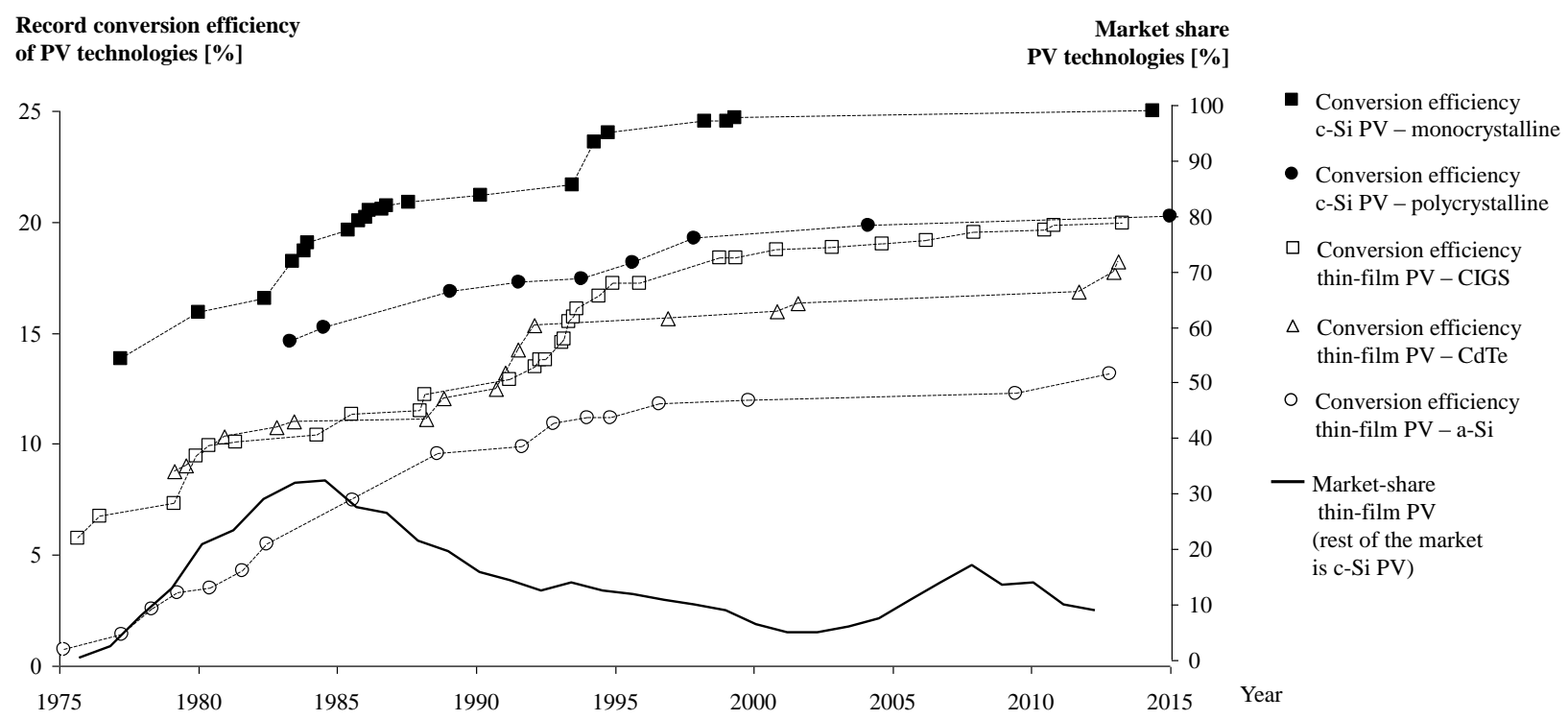

FIGURE 3: Development of conversion efficiencies and market share of c-Si PV and thin-film PV (Fraunhofer ISE, 2017; NREL, 2017)

We observe that executives at both NREL and Fraunhofer ISE systematically adjusted their framing tactics to the evolution of the technologies. While one might assume that changes in the evolution of the technology may lead to changes in framing dimensions (e.g., the extent to which actors focus on "progress" or "performance"), interestingly the use of individual dimensions in our case remained relatively stable over time. Instead of switching framing dimensions, executives adjusted to technology evolution by varying framing tactics - i.e. combining the framing dimensions differently through conclusion, conditioning, and concession.

Executives used conclusion when a technology's development was going well, since it allowed them to signal to resource providers that a current development would continue in the future. For example, NREL executives used conclusion to point to positive trends in conversion efficiencies during the 1980s, while Fraunhofer ISE employed this framing tactic in the face of c-Si's rising market share in the 1990s. In such contexts, conclusion provides a powerful tool to enhance the positive image of a technology among stakeholders, since a positive observation on one dimension 
is used to enhance expectations in another. For example, in 2002, a Fraunhofer manager stated that "The vision is that even in the year 2010 and beyond the main workhorse for PV power generation will still be the crystalline silicon wafer solar cell [...]. This vision is supported by the fact that in the last 15 years the global market share of crystalline silicon has steadily increased at the expense of the a-Si thin film technology" (D34). In this statement, the positive progress of c-Si PV is used to draw a conclusion about its prospects - a tactic that only works because c-Si PV has actually developed in a positive way.

Conditioning was used in times of particularly great uncertainty. For example, executives at both NREL and Fraunhofer ISE relied on it heavily during the 1980s and 1990s, when thin-film emerged as a new technology but both its performance and market outlook were very uncertain. As one executive noted, during this period "the entire field of photovoltaics was still far from being economic, and extrapolating into the future was difficult" (I15). Another executive confirmed that, particularly at this early stage, executives had to rely heavily on conditioning, since "the further you look into the future, the more uncertain everything becomes and the more scientific work is needed and done, which means that you can only make very tentative predictions" (I12).

Finally, concession was used when technology or market developments for the organizations' favored technologies were not going to plan, since it served to justify resource providers' continued investment despite such issues. We found that executives used concession to highlight both the merits of their own technology (despite its shortcomings) and the shortcomings of others' (despite their merits). For example, endorsing NREL's focus on thin-film in 1993, when its market share was plummeting and conversion efficiencies continued to lag behind, Jack Stone, the director of NREL's photovoltaic division, stated, “Thin films [...] typically have lower efficiencies. Ultimately, however, thin films will be necessary for producing low-cost electricity, because the bottom line - the cost per watt—is more important than the efficiency" (D45). Just four years later, Satyen K. Deb, the director 
of NREL's Center for Basic Sciences, used concession to undermine the viability of c-Si PV: "Although enormous progress has been made in reducing the cost of silicon-based technology, it is not certain whether it can meet our ultimate cost goals" (D46). In both statements, NREL executives sought to justify why, even though the performance and progress of thin-film was lagging behind c$\mathrm{Si}$, NREL continued to explore thin-film technologies. In this sense, the tactic of concession helped NREL secure important resources from stakeholders in times of negative technology evolution without risking its own credibility. Table A2 in Appendix A provides additional evidence for the influence of framing channels and technology evolution on the use of framing tactics.

\section{Emerging theoretical framework}

Figure 4 shows the theoretical framework we developed that illustrates how technology characteristics shape the strategic framing of technologies. We find that executives systematically draw on four dimensions (1) - potential, prospect, performance, and progress - and three tactics (2) - conclusion, conditioning, and concession - to frame technology expectations and beliefs. The framing dimensions describe whether, when framing a technology, executives stress the hypothetical performance of a technology at an undefined point in the future (potential), its predicted performance at a specific point in the future (prospect), its present performance (performance), or the change in its performance relative to some time in the past (progress). Framing tactics, in turn, describe how an actor combines the different dimensions when strategically framing a technology. Specifically, we observe that executives link the different dimensions by making claims about cause and effect (conclusion), positioning one dimension as the condition for another (conditioning), and offsetting shortcomings in one dimension with strengths in another (concession). 


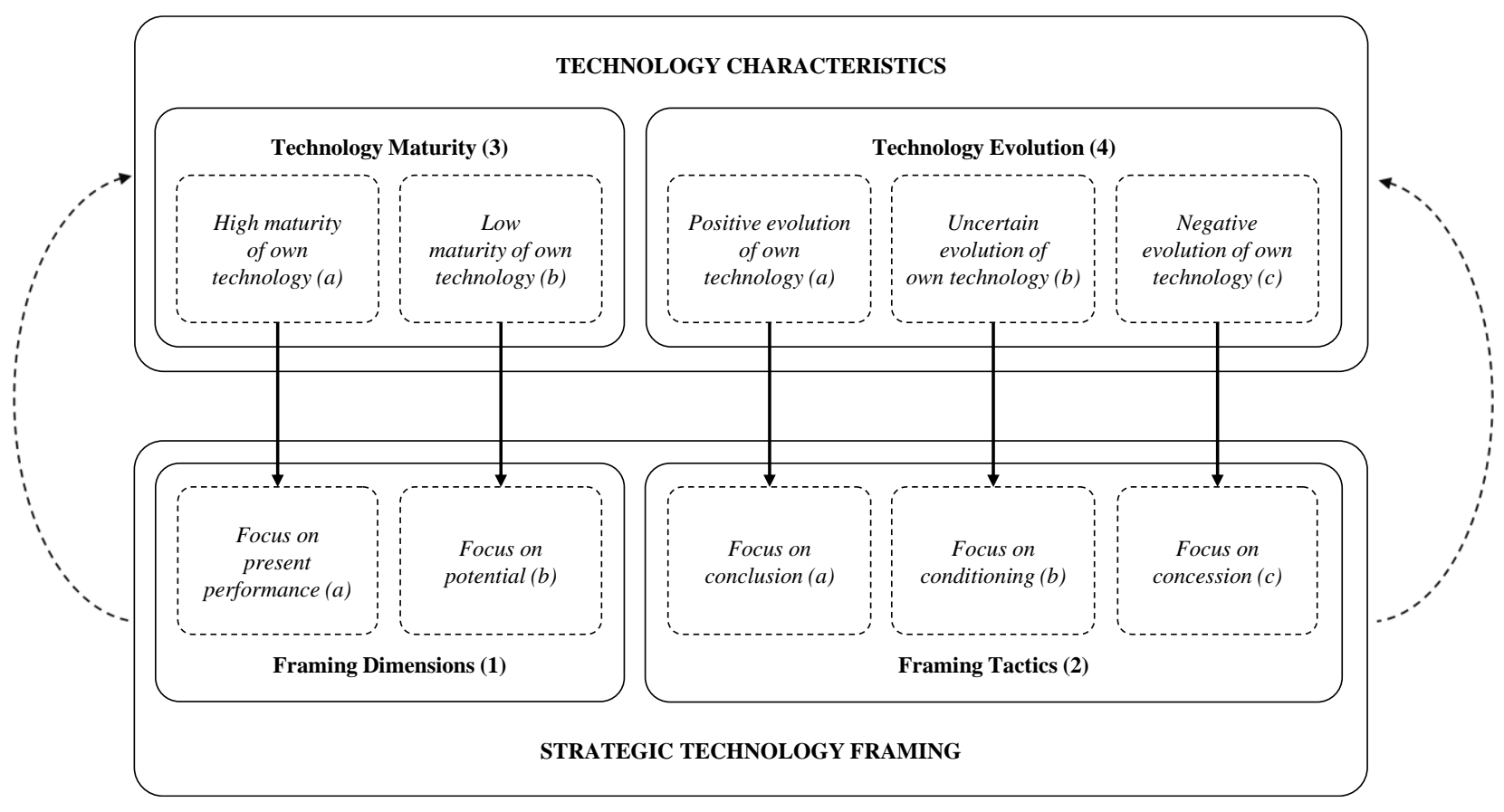

FIGURE 4: Theoretical model showing how technology characteristics influence the strategic framing of technologies

Our findings suggest that, in line with the literature, the use of framing dimensions and tactics is influenced by sociopolitical factors, such as the degree to which the framing resonates with the demands of key stakeholders and the framing channel. However, the framing dimensions and tactics are also directly shaped by material technology characteristics. Specifically, we show that technological maturity (3) shapes the use of framing dimensions. Even though in theory actors can freely choose among the different framing dimensions to shape expectations and beliefs regarding a specific technology, we find that actors whose firms pursue a more mature technology ( $3 a$ ) focus on framing the merits of their technology along the dimensions of performance (1a), whereas those whose firms pursue a less mature technology (3b) focus on the framing dimensions of potential (1b). Similarly, our findings indicate that the use of framing tactics (2) is strongly driven by technology evolution (4). Specifically, our findings indicate that when the technology of an organization evolves 
positively (4a), actors draw heavily on the framing tactic of conclusion (2a) to signal that the positive development in a specific dimension is likely to have a positive effect on other dimensions. When the evolution of technologies is uncertain (4b), actors draw more heavily on the tactic of conditioning (2b) to signal positive expectations while forestalling a loss of credibility if a forecast development does not materialize. Finally, when the evolution of the technology is negative (4c), actors fall back on the tactic of concession (2c) to emphasize that despite some shortcomings in a specific dimension (e.g., current performance or progress), the technology offers advantages in another (e.g., potential).

Our framework can be used to derive propositions about the impact of material technology characteristics on framing in other contexts. For example, we would generally expect new entrants working on novel technologies to make more use of potential and progress framing than incumbent firms that focus on more established technological solutions. Moreover, we would expect that organizations in industries characterized by a lower technological uncertainty than PV rely less on conditioning than the executives of the firms in our sample.

\section{DISCUSSION AND IMPLICATIONS}

\section{Implications for the literature}

\section{Social movements, institutional entrepreneurship, and impression management}

First, by developing a framework that highlights the role of materiality in strategic technology framing, our study contributes to the literature on social movements, institutional entrepreneurship, and impression management. This literature stresses that shaping others' beliefs and expectations involves developing narratives that weave social and material elements into coherent plots (Garud et al., 2014; Polkinghorne, 1988). Yet, extant empirical studies of strategic technology framing in this field have strongly focused on sociopolitical factors. This is not surprising, given that studies usually draw on frameworks rooted in institutional theory. At the same time, however, our study suggests 
that relying on this theoretical angle may have led to accounts of framing that underestimate (or at least insufficiently discuss) the role of material factors.

We show that material factors shape and constrain framing in important ways, suggesting that actors may have less agency than is currently assumed in many accounts of strategic technology framing. In this sense, this study complements existing frameworks building on institutional entrepreneurship and social movement theory by painting a more comprehensive picture of how material and sociopolitical factors jointly shape the strategic framing of technologies. This represents a first step toward a better understanding of what the social-movements literature calls "frame articulation," i.e. "the connection and alignment of events and experiences so that they hang together in a relatively unified and compelling fashion” (Benford and Snow, 2000: 623).

The literature on impression management has long dealt with the question of how individuals and organizations use language to portray events in a favorable light. In this context, scholars suggest that spokespersons use a number of tactics, such as justifications, denials, and references to organizational characteristics. In line with these findings, we show that representatives of NREL and Fraunhofer ISE used different tactics (conclusion, conditioning, and concession) when strategically framing technologies. However, in contrast to the literature on impression management, which focuses on how actors use framing to enhance their own legitimacy or image (Bolino et al., 2008), our study explains how actors are able to shape others' beliefs and expectations about technologies. Our framework thus provides a taxonomy for analyzing strategic framing in dimensions that are not covered by existing frameworks in the field of impression management. In this sense, we also answer recent calls for a closer investigation of how frames are constructed and evolve (Borah, 2011; Cornelissen and Werner, 2014; Kaplan and Tripsas, 2008). Moreover, our study demonstrates the merits of applying detailed syntactic and semantic analyses to the study of framing (Fillmore, 1976; 
Pan and Kosicki, 1993). As Cornelissen and Werner (2014) note, despite the importance of language structure for framing, such analyses have been largely absent from organizational research.

\section{Sociology of expectations}

Second, our study contributes to the literature on the sociology of expectations by providing insights into the detailed mechanisms through which technology characteristics shape actors' strategic framing of technologies. Previous research in this field has investigated how actors use verbal accounts to construct and contribute to the realization of expectations. Studies have started to investigate the role of materiality by showing that to build credible expectations, actors link the past, present, and future (Brown and Michael, 2003); describe the technology's performance, historical progress, path forward, and end targets (Bakker et al., 2012); and combine positive with more modest or negative statements (Gardner et al., 2015). However, since the main focus is on understanding how expectations shape materiality (rather than vice versa), this literature does not provide a coherent framework showing how actors' choice of framing elements depends on the specific characteristics of the framed technologies.

Addressing this shortcoming, we provide a novel taxonomy of technology framing and a theoretical framework (see Figure 4). Our taxonomy describes technology framing as consisting of two main elements: dimensions and tactics. In contrast to existing framing concepts such as diagnostic, prognostic, and motivational framing (Benford and Snow, 2000), which explain how actors mobilize action around a specific issue, our taxonomy focuses on explaining how actors strategically frame beliefs and expectations of a developing material entity.

The framework builds on and extends existing frameworks in the literature on sociology of expectations. For example, although our framing dimensions were inductively derived from the data, they show surprising similarities with Bakker et al.'s (2012) suggestion that "actors assess expectations as credible when they build on current performance and recent progress, the 
identification and construction of a path forward and a target performance level that the technological option is supposedly able to meet." Going beyond Bakker et al. (2012), however, we discuss how actors use framing tactics to link the different dimensions and provide detailed accounts of how the use of framing dimensions and tactics is linked to technology characteristics. Specifically, we show that framing dimensions are primarily driven by the maturity of the technology pursued by the actor and that the use of framing tactics strongly hinges on technology evolution. For example, even though in theory actors can freely choose among the different framing dimensions to shape the expectations and beliefs regarding a specific technology, executives at Fraunhofer ISE, which pursued a more mature and reliable PV technology, strongly focused on framing PV technology on the dimension of performance. In contrast, executives at NREL, which pursued a less mature but potentially cheaper technology, strongly framed PV technologies on the dimension of potential. Moreover, executives in both organizations varied their framing tactics in line with technology evolution. For example, whenever their own technology was making good progress, executives reverted to the tactic of conclusion to signal that positive developments would continue in the future. Whenever progress was slow, executives made use of concession to convey that despite some shortcomings their technology offered considerable advantages.

Borup et al. (2006, p. 287) suggest that "it has become increasingly important to develop a vocabulary and analytical perspectives with which to make sense of the promissory and futureoriented properties of innovation networks, especially given the highly contested character of expectations and futures." Similarly, Brown et al. (2003, p. 6) argue that "another foundational issue here is whether to see expectations as essentially rhetorical or material in character. [...] We have to further articulate the way in which these two phenomena relate to each other. That is, what are the routes of transmission between rhetoric and materiality?" By providing a coherent, integrative framework that describes how technology characteristics shape strategic technology framing, our 
study heeds these calls and provides a better understanding of the relationship between expectations and the material world.

\section{Technology hypes}

Finally, our study helps explain the role of framing in technology hypes. The literature suggests that hypes result from so-called "expectation races," where organizations create ever-higher expectations to secure resources from important stakeholders (Brown, 2003; Ruef and Markard, 2010). However, a puzzle is how organizations can generate narratives that are profoundly decoupled from material developments without losing credibility. We find intriguing indications that one answer might lie in actors closely tailoring framing to technology characteristics. One might assume that by including material factors in their framing, actors must reveal more about the actual merits and evolution of their technology. However, we show that by can generate accounts that, while true, serve to distract from unfavorable material developments. For example, by strategically selecting framing dimensions that highlight merits of the technology, and drawing on tactics that correspond with technology evolution, actors may be able to convey positive expectations about technologies despite observable shortcomings.

By showing how actors portray technologies in a positive light, our results also have implications for practice, since they could help executives infer material developments from framing patterns, making it easier to identify exaggerated claims and hypes. If, for example, actors continuously stress the potential—rather than the performance — of their technology over a long period of time, this may indicate a continued lack of a technological maturity, which may be problematic if stakeholders are interested in commercial/workable technologies. Particularly if stakeholders lack the expertise or information to independently check claims by technology developers, our study may help them avoid mis-investments and associated social costs (Borup et al., 
2006; Konrad et al., 2012). Overall, our framework therefore promises to improve the effectiveness of technology investments under uncertainty.

\section{Limitations and future research}

The limitations of our study suggest avenues for future research. First, our study is limited to the investigation of two research organizations. For-profit organizations (e.g., firms) differ from the organizations we investigated in terms of their primary purpose, their time horizons, and their sources of funding, which may influence framing patterns (Rip, 1994). Moreover, the impact of material technology characteristics on framing may differ depending on the accessibility of information by stakeholders. If actors' claims about technologies cannot be easily evaluated by the framing audience - e.g., because the artifact is not accessible to the public, or assessing its performance requires specific expertise - this may give actors more leeway to deviate from material developments. In fact, knowledge claims by members of the two research institutes we study are difficult for outsiders to assess, since the knowledge is often proprietary and highly specific. This suggests that material factors may play an even more important role for framing in other settings. Future research should thus validate and refine our findings by investigating framing in contexts different from ours.

Second, a challenge in our study was that the institutes we investigate differ not only in their technological choice but also in their funding sources (public vs. private) and home base (US vs. Germany), making it harder to link differences in framing to differences in technology characteristics. To distill the impact of technology characteristics, we drew on variation in funding sources over time, screened other research institutes in the respective countries, and used qualitative interviews. Based on these analyses, we find that the differences in funding sources and culture partly explain differences in framing tactics (see findings), but that technology characteristics provide an important, 
complementary explanation. However, given that our research does not allow us to specify the relative size of effects precisely, we call for future studies that verify our findings in alternative settings. In this context, researchers should also go beyond studying how material entities shape framing to investigate how they may directly influence expectations and beliefs (e.g., as actors directly experience pilot projects or prototypes).

Third, a limitation of our study lies in the fact that it takes the perspective of the framing organization rather than the audience. While this focus allows a more in-depth descriptions of framing techniques and antecedents, it provides limited insights into the effects of framing. Our data suggest that the framing used by the executives of NREL and Fraunhofer ISE was important for the organizations to continuously acquire resources in times of technological uncertainty. Amid considerable uncertainty over which technology would prevail, one would expect investors to be reluctant to fund organizations that have clearly committed to one technological option. Our findings suggest that framing technologies in a way that reflected both sociopolitical and material factors enabled the two organizations not only to survive, but to significantly increase their budgets over time. Since the effects of framing are beyond the scope of this paper, however, we call for future research that tests our propositions more formally and also investigates the effectiveness of alternative framing tactics. For example, future research could take the perspective of the audience in order to provide more details on the effectiveness of different methods of expectation framing under different conditions (Giorgi and Weber, 2015). One possible approach would be to systematically vary the use of framing dimensions and tactics in experiments and measure the effect on individuals' decision-making. In this context, it would also be interesting to study how the effectiveness of specific types of framing varies by audience type-for example, the general public vs. technology-savvy funding bodies. 


\section{CONCLUSION}

We develop a framework that describes how technology characteristics, such as the maturity and evolution of technologies, shape how actors publicly and purposefully frame technologies to influence important stakeholders. By highlighting the role of materiality, our study complements existing studies on strategic framing that draw on theories developed in the fields of social movements, institutional entrepreneurship, and impression management. By providing a coherent framework of how technology characteristics shape strategic technology framing, our work extends and integrates existing findings in the literature on the sociology of expectations. Moreover, by generating insights into how actors are able to frame technologies in a positive way despite observable shortcomings, our framework helps explain the emergence of technology hypes. In this sense, we believe that our framework of strategic technology framing holds much potential for future research that seeks to understand technology dynamics and the performance of organizations developing technologies in times of technological uncertainty. 


\section{REFERENCES}

Aldrich, H.E., Fiol, C.M., 1994. Fools rush in? The institutional context of industry creation. Academy of Management Review 19, 645-670.

Alkemade, F., Suurs, R.A., 2012. Patterns of expectations for emerging sustainable technologies. Technological Forecasting and Social Change 79, 448-456.

Anderson, P., Tushman, M.L., 1990. Technological discontinuities and dominant designs: A cyclical model of technological change. Administrative Science Quarterly 35, 604-633.

Bagnall, D.M., Boreland, M., 2008. Photovoltaic technologies. Energy Policy 36, 4390-4396.

Bakker, S., 2010. The car industry and the blow-out of the hydrogen hype. Energy Policy 38, 65406544.

Bakker, S., Budde, B., 2012. Technological hype and disappointment: lessons from the hydrogen and fuel cell case. Technology Analysis \& Strategic Management 24, 549-563.

Bakker, S., van Lente, H., Meeus, M.T., 2012. Credible expectations-The US Department of Energy's Hydrogen Program as enactor and selector of hydrogen technologies. Technological Forecasting and Social Change 79, 1059-1071.

Bator, R., Cialdini, R., 2000. The application of persuasion theory to the development of effective proenvironmental public service announcements. Journal of Social Issues 56, 527-542.

Benford, R.D., 1993. Frame disputes within the nuclear disarmament movement. Social Forces 71, 677-701.

Benford, R.D., Snow, D.A., 2000. Framing processes and social movements: An overview and assessment. Annual Review of Sociology 26, 611-639.

Benner, M.J., Tripsas, M., 2012. The influence of prior industry affiliation on framing in nascent industries: The evolution of digital cameras. Strategic Management Journal 33, 277-302.

Berkhout, F., 2006. Normative expectations in systems innovation. Technology Analysis \& Strategic Management 18, 299-311.

Bolino, M.C., Kacmar, K.M., Turnley, W.H., Gilstrap, J.B., 2008. A multi-level review of impression management motives and behaviors. Journal of Management 34, 1080-1109.

Borah, P., 2011. Conceptual issues in framing theory: A systematic examination of a decade's literature. Journal of Communication 61, 246-263.

Borup, M., Brown, N., Konrad, K., Van Lente, H., 2006. The sociology of expectations in science and technology. Technology Analysis \& Strategic Management 18, 285-298.

Brown, N., 2003. Hope against hype-accountability in biopasts, presents and futures. Science \& Technology Studies 28.

Brown, N., Michael, M., 2003. A sociology of expectations: retrospecting prospects and prospecting retrospects. Technology Analysis \& Strategic Management 15, 3-18.

Brown, N., Rip, A., Van Lente, H., 2003. Expectations in and about science and technology, Accessed online 08/09/2018: https://www.york.ac.uk/satsu/expectations/Utrecht\%202003/Background\%20paper\%20version \%2014May03.pdf.

Constant, E.W., 1980. The Origins of the Turbojet Revolution. Johns Hopkins Univ Press, Baltimore.

Cornelissen, J.P., Holt, R., Zundel, M., 2011. The role of analogy and metaphor in the framing and legitimization of strategic change. Organization Studies 32, 1701-1716.

Cornelissen, J.P., Werner, M.D., 2014. Putting framing in perspective: A review of framing and frame analysis across the management and organizational literature. Academy of Management Annals 8, 181-235. 
Creed, W.D., Scully, M.A., Austin, J.R., 2002. Clothes make the person? The tailoring of legitimating accounts and the social construction of identity. Organization Science 13, 475496.

Dosi, G., 1982. Technological paradigms and technological trajectories: A suggested interpretation of the determinants and directions of technical change. Research Policy 11, 147-162.

Eisenhardt, K.M., 1989. Building theories from case study research. Academy of Management Review 14, 532-550.

Eisenhardt, K.M., Graebner, M.E., 2007. Theory building from cases: Opportunities and challenges. Academy of Management Journal 50, 25-32.

Elsbach, K.D., 1994. Managing organizational legitimacy in the California cattle industry: The construction and effectiveness of verbal accounts. Administrative Science Quarterly 39, 57-88.

Elsbach, K.D., Sutton, R.I., Principe, K.E., 1998. Averting expected challenges through anticipatory impression management: A study of hospital billing. Organization Science 9, 6886.

Fillmore, C.J., 1976. Frame semantics and the nature of language. Annals of the New York Academy of Sciences 280, 20-32.

Fiss, P.C., Hirsch, P.M., 2005. The discourse of globalization: Framing and sensemaking of an emerging concept. American Sociological Review 70, 29-52.

Fiss, P.C., Zajac, E.J., 2006. The symbolic management of strategic change: Sensegiving via framing and decoupling. Academy of Management Journal 49, 1173-1193.

Fleiss, J.L., Levin, B., Paik, M.C., 2003. Statistical Methods for Rates and Proportions. John Wiley $\&$ Sons, Hoboken, NJ.

Fraunhofer ISE, 2017. Photovoltaics Report, Accessed online 08/03/2017: https://www.ise.fraunhofer.de/content/dam/ise/de/documents/publications/studies/Photovoltaic s-Report.pdf.

Frickel, S., Gross, N., 2005. A general theory of scientific/intellectual movements. American Sociological Review 70, 204-232.

Gardner, J., Samuel, G., Williams, C., 2015. Sociology of low expectations: Recalibration as innovation work in biomedicine. Science, Technology, \& Human Values 40, 998-1021.

Garud, R., Jain, S., Kumaraswamy, A., 2002. Institutional entrepreneurship in the sponsorship of common technological standards: The case of Sun Microsystems and Java. Academy of Management Journal 45, 196-214.

Garud, R., Rappa, M.A., 1994. A socio-cognitive model of technology evolution: The case of cochlear implants. Organization Science 5, 344-362.

Garud, R., Schildt, H.A., Lant, T.K., 2014. Entrepreneurial storytelling, future expectations, and the paradox of legitimacy. Organization Science 25, 1479-1492.

Gibbert, M., Ruigrok, W., Wicki, B., 2008. What passes as a rigorous case study? Strategic Management Journal 29, 1465-1474.

Gilbert, C.G., 2006. Change in the presence of residual fit: Can competing frames coexist? Organization Science 17, 150-167.

Gioia, D.A., Chittipeddi, K., 1991. Sensemaking and sensegiving in strategic change initiation. Strategic Management Journal 12, 433-448.

Gioia, D.A., Corley, K.G., Hamilton, A.L., 2013. Seeking qualitative rigor in inductive research: Notes on the Gioia methodology. Organizational Research Methods 16, 15-31.

Giorgi, S., Weber, K., 2015. Marks of distinction: Framing and audience appreciation in the context of investment advice. Administrative Science Quarterly 60, 333-367.

Goffman, I., 1974. Frame Analysis. Harper, New York. 
Gray, B., Purdy, J.M., Ansari, S.S., 2015. From interactions to institutions: Microprocesses of framing and mechanisms for the structuring of institutional fields. Academy of Management Review 40, 115-143.

Green, S.E., Li, Y., Nohria, N., 2009. Suspended in self-spun webs of significance: A rhetorical model of institutionalization and institutionally embedded agency. Academy of Management Journal 52, 11-36.

Gurses, K., Ozcan, P., 2015. Entrepreneurship in regulated markets: framing contests and collective action to introduce Pay TV in the US. Academy of Management Journal 58, 1709-1739.

Hallahan, K., 1999. Seven models of framing: Implications for public relations. Journal of Public Relations Research 11, 205-242.

Hoppmann, J., Peters, M., Schneider, M., Hoffmann, V.H., 2013. The two faces of market support How deployment policies affect technological exploration and exploitation in the solar photovoltaic industry. Research Policy 42, 989-1003.

Jasanoff, S.S., 1987. Contested boundaries in policy-relevant science. Social Studies of Science 17, 195-230.

Kaplan, S., 2008. Framing contests: Strategy making under uncertainty. Organization Science 19, 729-752.

Kaplan, S., Murray, F., 2010. Entrepreneurship and the construction of value in biotechnology. Research in the Sociology of Organizations 29, 107-147.

Kaplan, S., Tripsas, M., 2008. Thinking about technology: Applying a cognitive lens to technical change. Research Policy 37, 790-805.

Kellogg, K.C., 2011. Hot lights and cold steel: Cultural and political toolkits for practice change in surgery. Organization Science 22, 482-502.

Kennedy, M.T., Fiss, P.C., 2009. Institutionalization, framing, and diffusion: The logic of TQM adoption and implementation decisions among US hospitals. Academy of Management Journal 52, 897-918.

Konrad, K., 2006. The social dynamics of expectations: the interaction of collective and actorspecific expectations on electronic commerce and interactive television. Technology Analysis \& Strategic Management 18, 429-444.

Konrad, K., Markard, J., Ruef, A., Truffer, B., 2012. Strategic responses to fuel cell hype and disappointment. Technological Forecasting and Social Change 79, 1084-1098.

Koopmans, R., Statham, P., 1999. Ethnic and civic conceptions of nationhood and the differential success of the extreme right in Germany and Italy, in: Giugni, M., McAdam, D., Tilly, C. (Eds.), How Social Movements Matter. University of Minnesota Press, Minneapolis, pp. 225251.

Lampel, J., 2001. Show-and-tell: product demonstrations and path creation of technological change, in: Garud, R., Karnøe, P. (Eds.), Path Dependence and Creation. Lawrence Erlbaum Associates, Mahwah, NJ, pp. 303-328.

Langley, A., Abdallah, C., 2011. Templates and turns in qualitative studies of strategy and management. Research Methodology in Strategy and Management 6, 201-235.

Leary, M.R., Kowalski, R.M., 1990. Impression management: A literature review and twocomponent model. Psychological Bulletin 107, 34-47.

Leonardi, P.M., 2012. Materiality, sociomateriality, and socio-technical systems: what do these terms mean? How are they related? Do we need them?, in: Leonardi, P.M., Nardi, B.A., Kallinikos, J. (Eds.), Materiality and Organizing: Social Interaction in a Technological World. Oxford University Press, Oxford, pp. 25-48. 
Leonardi, P.M., 2013. Theoretical foundations for the study of sociomateriality. Information and Organization 23, 59-76.

Leonardi, P.M., Barley, S.R., 2010. What's under construction here? Social action, materiality, and power in constructivist studies of technology and organizing. Academy of Management Annals $4,1-51$.

Lounsbury, M., Glynn, M.A., 2001. Cultural entrepreneurship: Stories, legitimacy, and the acquisition of resources. Strategic Management Journal 22, 545-564.

Maitlis, S., Lawrence, T.B., 2007. Triggers and enablers of sensegiving in organizations. Academy of Management Journal 50, 57-84.

Marcus, A.A., Goodman, R.S., 1991. Victims and shareholders: The dilemmas of presenting corporate policy during a crisis. Academy of Management Journal 34, 281-305.

Martens, M.L., Jennings, J.E., Jennings, P.D., 2007. Do the stories they tell get them the money they need? The role of entrepreneurial narratives in resource acquisition. Academy of Management Journal 50, 1107-1132.

McCammon, H.J., Muse, C.S., Newman, H.D., Terrell, T.M., 2007. Movement framing and discursive opportunity structures: The political successes of the US women's jury movements. American Sociological Review 72, 725-749.

McInerney, P.B., 2008. Showdown at Kykuit: Field-configuring events as loci for conventionalizing accounts. Journal of Management Studies 45, 1089-1116.

Moreira, T., Palladino, P., 2005. Between truth and hope: on Parkinson's disease, neurotransplantation and the production of the 'self'. History of the Human Sciences 18, 5582.

Nerlich, B., Halliday, C., 2007. Avian flu: the creation of expectations in the interplay between science and the media. Sociology of Health \& Illness 29, 46-65.

NREL, 2017. Research Cell Efficiency Records, Accessed online 08/02/2017: https://www.nrel.gov/pv/assets/images/efficiency-chart.png.

Orlikowski, W.J., 2007. Sociomaterial practices: Exploring technology at work. Organization Studies 28, 1435-1448.

Orlikowski, W.J., 2008. Using technology and constituting structures: A practice lens for studying technology in organizations, in: Ackerman, M.S., Halverson, C.A., Erickson, T., Kellogg, W.A. (Eds.), Resources, Co-evolution and Artifacts: Theory in CSCW. Springer, London pp. 255-305.

Orlikowski, W.J., Scott, S.V., 2008. Sociomateriality: Challenging the separation of technology, work and organization. Academy of Management Annals 2, 433-474.

Pan, Z., Kosicki, G.M., 1993. Framing analysis: An approach to news discourse. Political Communication 10, 55-75.

Pinch, T.J., Bijker, W.E., 1984. The social construction of facts and artefacts: Or how the sociology of science and the sociology of technology might benefit each other. Social Studies of Science $14,399-441$.

Polkinghorne, D.E., 1988. Narrative Knowing and the Human Sciences. State University of New York Press, New York.

Rhee, E., Fiss, P., 2014. Framing controversial actions: Regulatory focus, source credibility, and stock market reaction to poison pill adoption. Academy of Management Journal 57, 1734 1758.

Rip, A., 1994. The republic of science in the 1990s. Higher Education 28, 3-23. 
Ruef, A., Markard, J., 2010. What happens after a hype? How changing expectations affected innovation activities in the case of stationary fuel cells. Technology Analysis \& Strategic Management 22, 317-338.

Santos, F.M., Eisenhardt, K.M., 2009. Constructing markets and shaping boundaries: Entrepreneurial power in nascent fields. Academy of Management Journal 52, 643-671.

Schlenker, B.R., 1980. Impression Management. Brooks/Cole Publishing Company Monterey, CA.

Snow, D.A., Benford, R.D., 1988. Ideology, frame resonance, and participant mobilization. International Social Movement Research 1, 197-217.

Snow, D.A., Rochford Jr, E.B., Worden, S.K., Benford, R.D., 1986. Frame alignment processes, micromobilization, and movement participation. American Sociological Review 51, 464-481.

Sonenshein, S., 2010. We're changing - Or are we? Untangling the role of progressive, regressive, and stability narratives during strategic change implementation. Academy of Management Journal 53, 477-512.

Staw, B.M., McKechnie, P.I., Puffer, S.M., 1983. The justification of organizational performance. Administrative Science Quarterly 28, 582-600.

Sutton, R.I., Callahan, A.L., 1987. The stigma of bankruptcy: Spoiled organizational image and its management. Academy of Management Journal 30, 405-436.

Tilly, C., 2006. Why? What Happens When People Give Reasons... and Why.

Tushman, M.L., Anderson, P., 1986. Technological discontinuities and organizational environments. Administrative Science Quarterly 31, 439-465.

Tutton, R., 2011. Promising pessimism: Reading the futures to be avoided in biotech. Social Studies of Science 41, 411-429.

Van den Belt, H., Rip, A., 1987. The Nelson-Winter-Dosi model and synthetic dye chemistry, in: Bijker, W.E., Hugbes, T., Pinch, T. (Eds.), The Social Construction of Technological Systems. New Directions in the Sociology and History of Technology. MIT Press, Cambridge, MA, pp. 135-158.

Van Lente, H., 1993. Promising technology. The dynamics of expectations in technological developments. University of Twente, Twente, Netherlands.

Van Lente, H., 2000. Forceful futures: from promise to requirement, in: Brown, R., Rappert, B., Webster, A. (Eds.), Contested Futures. A Sociology of Prospective Techno-Science. Ashgate Publishing, Aldershot, UK, pp. 43-64.

Van Lente, H., 2012. Navigating foresight in a sea of expectations: lessons from the sociology of expectations. Technology Analysis \& Strategic Management 24, 769-782.

Van Lente, H., Bakker, S., 2010. Competing expectations: the case of hydrogen storage technologies. Technology Analysis \& Strategic Management 22, 693-709.

Weick, K.E., 1979. The Social Psychology of Organizing. Random House, New York.

Weick, K.E., 2007. The generative properties of richness. Academy of Management Journal 50, 1419.

Werner, M.D., Cornelissen, J.P., 2014. Framing the change: Switching and blending frames and their role in instigating institutional change. Organization Studies 35, 1449-1472.

Yin, R.K., 2009. Case Study Research: Design and Methods, Fourth Edition ed. Sage Publications, Thousand Oaks. 


\section{APPENDIX A}

TABLE A1: Evidence for drivers of framing dimensions

\begin{tabular}{|c|c|}
\hline Driver & Exemplary quotes \\
\hline \multirow{4}{*}{$\begin{array}{l}\text { Stakeholder } \\
\text { demands }\end{array}$} & $\begin{array}{l}\text { "We stress progress because we need to do science marketing. Whenever someone has a new result, we write a press release. Our } \\
\text { PR department issues two, three press releases per month, and that is simply acquisition [i.e. fundraising]. We need to stay on the } \\
\text { radar of industry, the public funding agencies, and the EU. We talk less about potential because we develop solar cells for the } \\
\text { industry that you can manufacture at low costs and high conversion efficiencies." (I6) }\end{array}$ \\
\hline & $\begin{array}{l}\text { "At Fraunhofer, we need to stay close to practice, to ensure our funding, particularly to achieve our share of industry funding [...] } \\
\text { That forces us to stay very realistic [...] NREL is different, it's a government lab. You can do more basic research there." (I12) }\end{array}$ \\
\hline & $\begin{array}{l}\text { "And the DOE is funding something that is a little further out, that is breakthrough, that cannot easily be perceived as being an } \\
\text { incremental effort that could just as well be done by industry. That is very important for their own reputation and standing with } \\
\text { Congress." (I3) }\end{array}$ \\
\hline & $\begin{array}{l}\text { "It is a strategic decision of NREL to address future potential and act accordingly. A Fraunhofer institute needs to be close to } \\
\text { industry and work on issues related to progress." (I1) }\end{array}$ \\
\hline \multirow{4}{*}{$\begin{array}{l}\text { Technology } \\
\text { maturity }\end{array}$} & $\begin{array}{l}\text { "Potential, I mean, this is the reason why we wanted to do thin-film, because we thought it could be a hundred times cheaper. [...] } \\
\text { Performance; clearly, performance is the strength of [crystalline] silicon. The potential was considered to be low, but that didn't } \\
\text { turn out to be true." (I15) }\end{array}$ \\
\hline & $\begin{array}{l}\text { "And if someone just came along and said, 'Hey, thin-film is the best there is and you can forget about crystalline silicon!' you'd } \\
\text { soon lose credibility if the facts told a different story. [...] The potential for thin-film exists, it simply hasn't been realized yet." (I9) }\end{array}$ \\
\hline & $\begin{array}{l}\text { "Certainly, the third-generation PV guys are going to be framing on potential almost exclusively, because they really don't have } \\
\text { progress like you would think about when you think of the efficiency for a manufacturable device." (I13) }\end{array}$ \\
\hline & "In terms of potential, one could still think of an argument why thin-film is superior." (I15) \\
\hline
\end{tabular}

TABLE A2: Evidence for drivers of framing tactics

\begin{tabular}{|c|c|}
\hline Driver & Exemplary quotes \\
\hline \multirow{4}{*}{ Framing channels } & $\begin{array}{l}\text { "You would frame things differently. The journalist, of course, needs to portray things in a completely simplified way because } \\
\text { readers won't buy very complicated things- - whereas the scientist notices the details and is only interested in genuinely new } \\
\text { things." (I12) }\end{array}$ \\
\hline & $\begin{array}{l}\text { "Conference presentations and journal articles are identical [in terms of how things are being framed], there's no big difference. } \\
\text { When talking to newspapers you use broad brush-strokes and need to simplify. For them, you can't try to compare five different } \\
\text { technologies with each other. You need to argue in a more straightforward fashion. But you also shouldn't be biased, or come to } \\
\text { a wrong conclusion." (I6) }\end{array}$ \\
\hline & "[At a conference] one would say, there's negative and positive aspects, what's usually the case." (I12) \\
\hline & $\begin{array}{l}\text { "You wouldn't go down well at a conference [if you simplified things too much]. It would raise questions straight away: 'That's } \\
\text { not realistic, what you say there. And there's this and that that's also important. And you can't say it like that."'(I12) }\end{array}$ \\
\hline \multirow{5}{*}{$\begin{array}{l}\text { Technology } \\
\text { evolution }\end{array}$} & $\begin{array}{l}\text { "All these statements are based on technological development, which we really believe in. At least, that's my personal } \\
\text { conviction." (I2) }\end{array}$ \\
\hline & $\begin{array}{l}\text { "I mean, the technology has evolved. Costs have come down, conversion efficiencies have gone up, and in the last couple of } \\
\text { years industrial production has risen and is still rising at an astonishing rate. That's correlated with the less favorable outlook for } \\
\text { thin-film technologies." (I6) }\end{array}$ \\
\hline & $\begin{array}{l}\text { "If you had asked me } 10 \text { years ago if we would really have a } 50 \text {-per-cent-efficiency solar cell, I would have said that I wouldn't } \\
\text { think so. [...] Today, after } 10 \text { years of research, I see that we can make the } 50 \text { per cent goal. [...] You see how things can change. } \\
\text { I really believe that scientists are driven by the solid ground they have under their feet." (I1) }\end{array}$ \\
\hline & "Crystalline silicon showed that it has the potential to become cheap, which had been in doubt before." (I12) \\
\hline & "A prediction in 2012 is a little easier than a prediction in 1984." (I13) \\
\hline
\end{tabular}




\section{ACKNOWLEDGEMENTS}

We acknowledge valuable comments by Pamela Barr, Shiko Ben-Menahem, Mary Benner, Catharina Bening, Aoife Brophy Haney, Peer Fiss, Jennifer Howard-Grenville, Stefano Brusoni, Raghu Garud, Sarah Kaplan, Volker Hoffmann, Joern Huenteler, Jochen Markard, Daniella Laureiro Martinez, Johannes Meuer, Johann Peter Murmann, Claus Rerup, William Ocasio, and Charlene Zietsma on earlier drafts of this paper. We thank Tom Albrighton and Diana Perry Schnelle for their editorial assistance. We owe special thanks to the participants in the Managerial and Organizational Attention Research Workshop, Zurich, 2013, who provided very helpful feedback on the manuscript. Finally, we would like to acknowledge the support of the Science, Technology and Public Policy Program at the Belfer Center for Science and International Affairs at Harvard University. J. Hoppmann's contribution was financially supported by the CREST, which is financially supported by Innosuisse, the Swiss Innovation Agency [grant 1155000154]. L. D. Anadón would like to acknowledge funding from the European Union's Horizon 2020 research and innovation programme [grant agreement 730403 - INNOPATHS]. 